\title{
Lhx3-Chx10 Reticulospinal Neurons in Locomotor Circuits
}

\author{
Frédéric Bretzner ${ }^{1,2,3}$ and Robert M. Brownstone ${ }^{3,4}$ \\ ${ }^{1}$ Centre de Recherche du CHU de Québec, CHUL-Neurosciences, Québec City, Québec G1V 4G2, Canada, ${ }^{2}$ Département de Psychiatrie et Neurosciences, \\ Université Laval, Québec City, Québec G1K 7P4, Canada, ${ }^{3}$ Department of Medical Neuroscience, Dalhousie University, Halifax, Nova Scotia B3H 4R2, \\ Canada, and ${ }^{4}$ Department of Surgery (Neurosurgery), Dalhousie University, Halifax, Nova Scotia B3H 4R2, Canada
}

Motor behaviors result from the interplay between the brain and the spinal cord. Reticulospinal neurons, situated between the supraspinal structures that initiate motor movements and the spinal cord that executes them, play key integrative roles in these behaviors. However, the molecular identities of mammalian reticular formation neurons that mediate motor behaviors have not yet been determined, thus limiting their study in health and disease. In the medullary reticular formation of the mouse, we identified neurons that express the transcription factors $\mathrm{Lhx} 3$ and/or Chx10, and demonstrate that these neurons form a significant component of glutamatergic reticulospinal pathways. Lhx3-positive medullary reticular formation neurons express Fos following a locomotor task in the adult, indicating that they are active during walking. Furthermore, they receive functional inputs from the mesencephalic locomotor region and have electrophysiological properties to support tonic repetitive firing, both of which are necessary for neurons that mediate the descending command for locomotion. Together, these results suggest that Lhx3/Chx10 medullary reticular formation neurons are involved in locomotion.

\section{Introduction}

Goal-directed movements result from interplay between the brain and the spinal cord. The brain selects and plans the motor programs, and transmits motor commands from the brainstem to the spinal cord, which in turn translates these commands into motor action. While progress has been made in understanding motor commands in the forebrain (Drew et al., 2004; Bretzner and Drew, 2005) and integration in the spinal cord (Brownstone and Bui, 2010), less in known about the brainstem neurons that play key integrative roles in producing movement.

One movement on which studies of neural circuits have been focused is locomotion. In the 1960s, Shik and Orlovsky identified the mesencephalic locomotor region (MLR) in the dorsal aspect of the mesopontine tegmentum as a key center that initiates locomotion (Shik et al., 1966). Tonic stimulation of the MLR in decerebrate cats initiates coordinated four-limbed locomotor activity. The MLR command signal is integrated in the medullary reticular formation (medRF; Garcia-Rill and Skinner, 1987b; Jordan, 1998; Deliagina et al., 2002; Zaporozhets et al., 2004; Dubuc et al., 2008; Mullins et al., 2011), likely within both gigantocellu-

Received Nov. 7, 2012; revised June 20, 2013; accepted July 25, 2013.

Author contributions: F.B. and R.M.B. designed research; F.B. performed research; F.B. and R.M.B. contributed unpublished reagents/analytic tools; F.B. and R.M.B. analyzed data; F.B. and R.M.B. wrote the paper.

This work was funded by the Canadian Institutes of Health Research (FRN 89820). We thank Drs. Larry Jordan, Tuan Bui, and Silvia Arber for their comments on the manuscript; Pratip Mitra, and Izabela Panek for helpful discussions; and Angelita Alcos, Bithika Ray, Nadia Farbstein, Stephen Whitefield, Damaso Sadi, Laura Baxter, Julian Green, and Meggie Reardon for technical support. We thank Drs. Gerald Zamponi and Terry Snutch for the anti-CaV3 antibodies; and Nathaniel Heintz, The Rockefeller University, Charles Gerfen, National Institutes of Health, and the Mutant Mouse Regional Resource Center for the Chx10::eGFP mice. F.B. was a Canadian Institutes of Health Research and Paralysis Project of America postdoctoral fellowship recipient.

Correspondence should be addressed to Rob Brownstone, Departments of Surgery (Neurosurgery) and Medical Neuroscience, Dalhousie University, P.O. Box 15000, Halifax, Nova Scotia, Canada B3H 4R2. E-mail: Rob.Brownstone@dal.ca.

DOI:10.1523/JNEUROSCI.5231-12.2013

Copyright $\odot 2013$ the authors $\quad 0270-6474 / 13 / 3314681-12 \$ 15.00 / 0$ lar and magnocellular reticular nuclei (Mori et al., 1978; Shefchyk et al., 1984; Mori, 1987; Noga et al., 2003). The reticulospinal pathway that recruits spinal locomotor circuits is a fastconducting (Orlovskilu, 1970; Degtyarenko et al., 1998; Noga et al., 2003), glutamatergic (Douglas et al., 1993; Jordan, 1998; Hägglund et al., 2010) pathway that works in concert with raphespinal serotonergic systems (Liu and Jordan, 2005). However, the identity and properties of the involved mammalian reticulospinal neurons remain largely unknown.

The advent of genetic techniques has led to the identification and characterization of specific populations of neurons involved in motor systems (Lee and Pfaff, 2001; Kiehn, 2006; Goulding, 2009; McLean and Fetcho, 2011). For example, it is possible to drive persistent expression of fluorescent proteins in genetically defined neuronal populations so as to target these neurons for anatomical, molecular, and physiological studies (Pierani et al., 2001; Lanuza et al., 2004; Wilson et al., 2005, 2010). Like in the spinal cord (Sharma et al., 1998; Al-Mosawie et al., 2007; Lundfald et al., 2007; Dougherty and Kiehn, 2010), the transcription factors Lhx3 and Chx10 are expressed in the medRF (CepedaNieto et al., 2005; Hafler et al., 2008; Kinkhabwala et al., 2011; Koyama et al., 2011; Crone et al., 2012). In the zebrafish, hindbrain Chx10 cells are glutamatergic, rhythmically active, and provide excitation to the spinal cord during swimming (Kinkhabwala et al., 2011; Kimura et al., 2013). Therefore, in seeking neurons in the medRF that project to the spinal cord and may be involved in movement in limbed animals, we studied mouse Lhx3-expressing and Chx10-expressing neurons and their potential role in locomotion.

We show here that the transcription factors Lhx 3 and Chx 10 define populations of glutamatergic neurons in the medRF that project to the spinal cord, receive functional inputs from the MLR, and are activated in locomotion. These data support the 
A

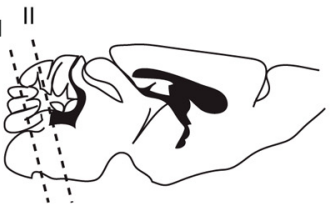

B

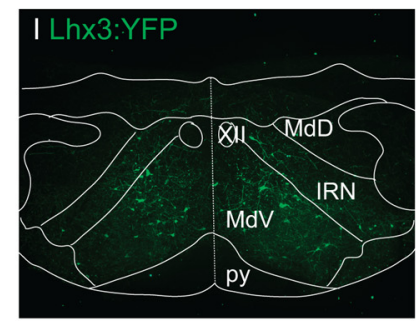

D

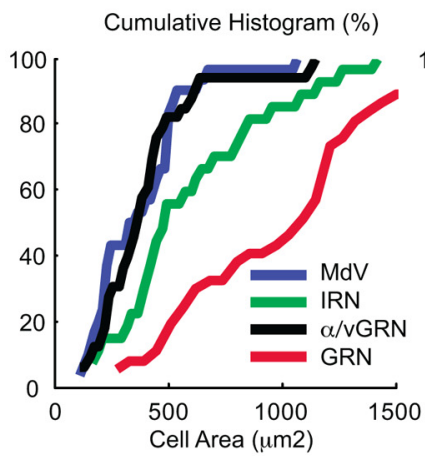

H Lhx3 and Gata2/3 expression

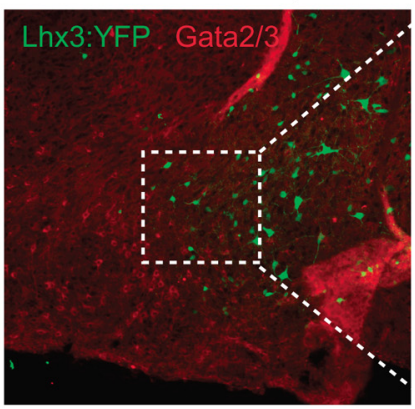

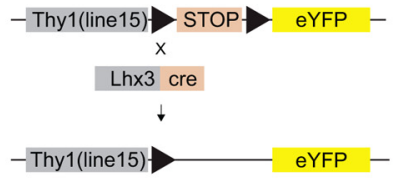

Rostral Medulla

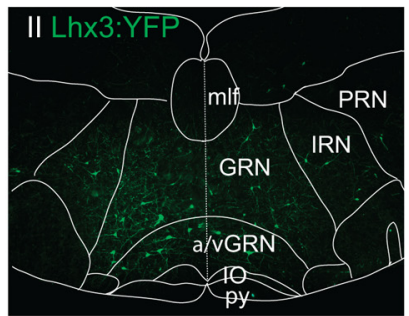

E

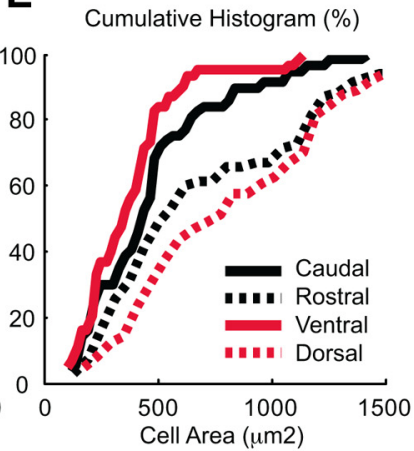

$F$
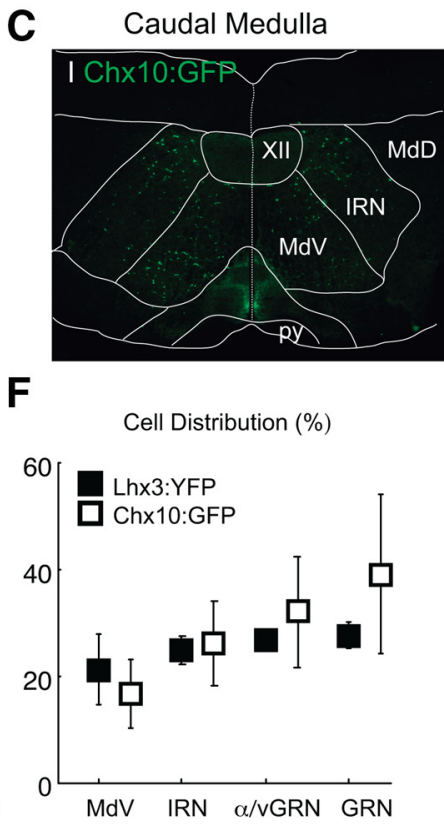

F

I Lhx3 and Chx10 expression
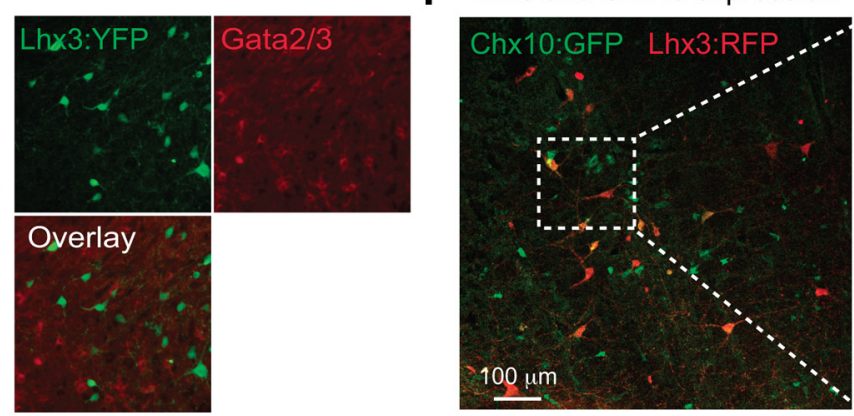

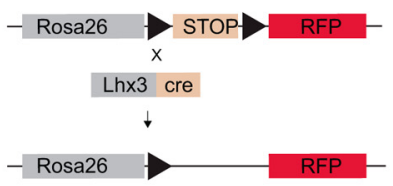

Rostral Medulla

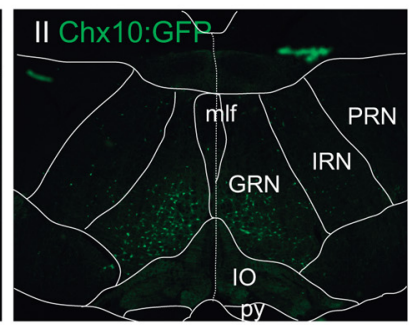

G
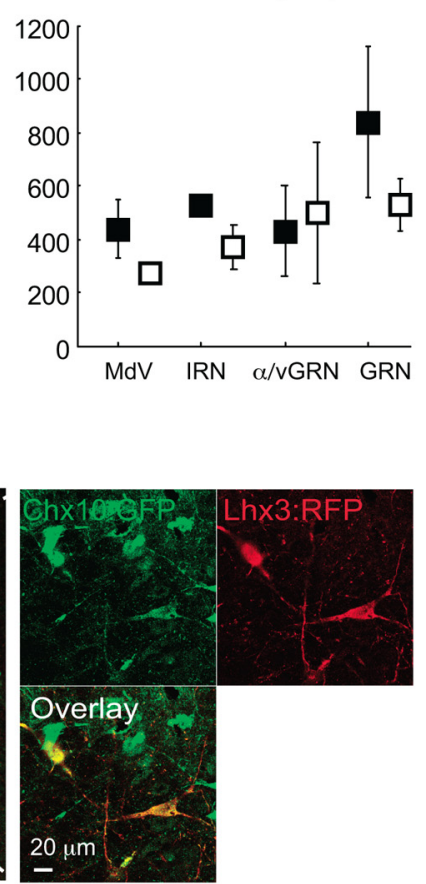

Figure 1. Anatomical characterization of $L h \times 3$ and $C h x 10$ medRF neurons. $A$, Genetic constructs and levels of transverse sections in the sagittal plane. $B, C$, Low-magnification images of adult Lhx3-YFP $(\boldsymbol{B})$ and Chx10::GFP ( $\boldsymbol{C}$ ) brainstem coronal sections. D, Cumulative histograms for Lhx3-YFP medRF neuron area in four medRF nuclei. $\boldsymbol{E}$, Cumulative histograms for Lhx3-YFP medRF neuron area across rostrocaudal and ventrodorsal axes. Note a similar pattern was observed for Chx10::GFP medRF neurons (data not shown). F, Cell distribution (mean and STD) of Lhx3-YFP (filled squares) and Chx10::GFP (open squares) neurons across medRF nuclei. G, Areas (mean and STD) of Lhx3-YFP and Chx10::GFP medRF neurons across medRF nuclei. $\boldsymbol{H}$, Absence of overlap between Lhx3-YFP (green) and Gata2/3 (red) medRF neurons.I, Overlap of Lhx3-RFP (red) and Chx10::GFP (green) medRF neurons. py, Pyramide; mlf, medial longitudinal fasciculus; I0, inferior olive; MdD, dorsal aspect of the medullary reticular formation; XII, hypoglossal nucleus.

hypothesis that Lhx3/Chx10 reticulospinal neurons are involved in mediating a descending motor command for locomotion.

\section{Materials and Methods}

All procedures were in accordance with protocols approved by the Dalhousie University Committee on Laboratory Animals and conformed to the standards of the Canadian Council for Animal Care. Figures reported and bars shown are means \pm SDs.

Mouse strains. The following mice of either sex were used in various combinations: Lhx3 ${ }^{\text {cre/+ }}$ (Sharma et al., 1998), thyl-loxP-stop-loxP-YFP reporter line 15 (thyl-fs-YFP, yellow fluorescent protein; Feng et al., 2000; Al-Mosawie et al., 2007), Rosa26-loxP-stop-loxP-tdTomato [Rosa26-fstdTomato, Jackson Labs; when crossed with Lhx $3^{\text {cre/+ }}$, termed Lhx3-YFP or Lhx3-RFP (red fluorescent protein) mice respectively], BAC Chx10::eGFP
(Mutant Mouse Regional Resource Center, University of California, Davis); and BAC GAD67::eGFP (Gong et al., 2003; Jackson Labs).

The use of Lhx $3^{\text {cre/+ }}$ mice has the advantage that the neurons can be genetically manipulated, but suffers from incomplete recombination (Al-Mosawie et al., 2007). The Chx10::eGFP mice provided more complete labeling of this neuronal population. Therefore, both types were used in this study.

Immunohistochemistry, in situ hybridization, tracing, and imaging. Mice were anesthetized with ketamine and transcardially perfused with $0.9 \%$ saline followed by $4 \%$ paraformaldehyde in $0.1 \mathrm{~m}$ phosphate buffer, $\mathrm{pH}$ 7.4. Tissues were harvested, postfixed in $4 \%$ paraformaldehyde overnight, and subsequently cryoprotected in $30 \%$ sucrose. As previously described, immunohistochemistry was performed on cryostat cut sections mounted on slides (Bretzner et al., 2010) or microtome cut floating 


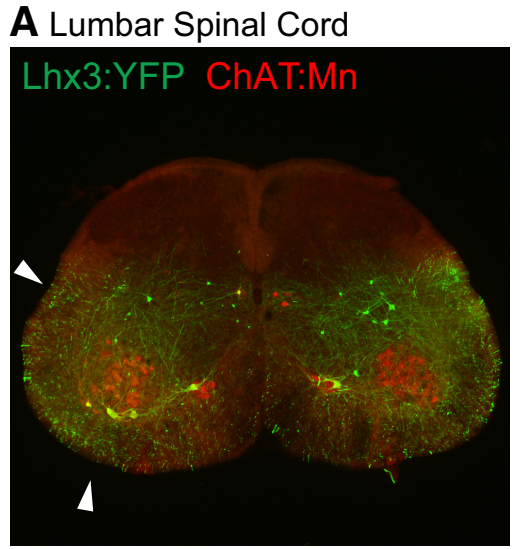

\begin{abstract}
B Neonatal Isolated BrainstemSpinal Cord preparation superfused with aCSF
\end{abstract}

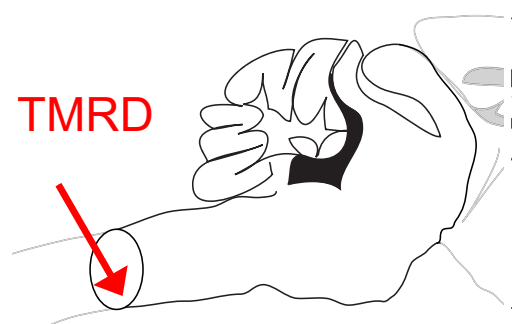

\section{Reticulospinal Neurons}

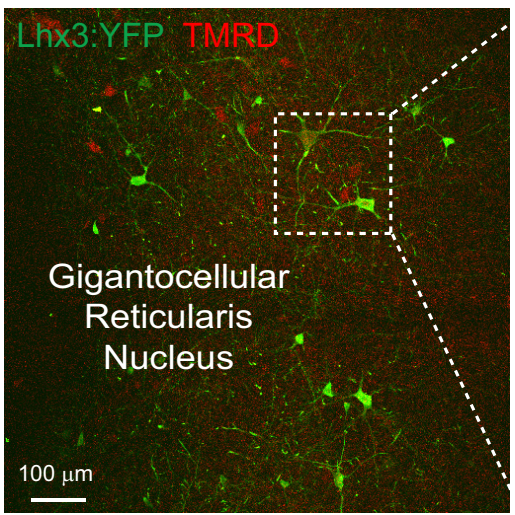

\section{Proportion}

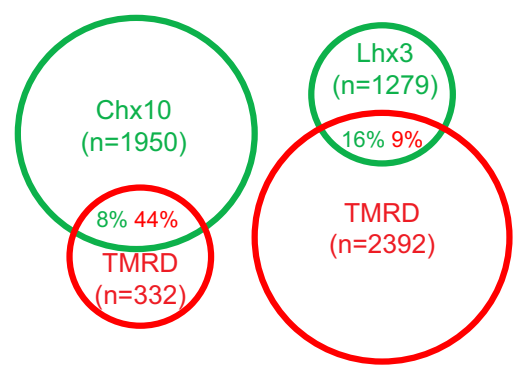

High magnification

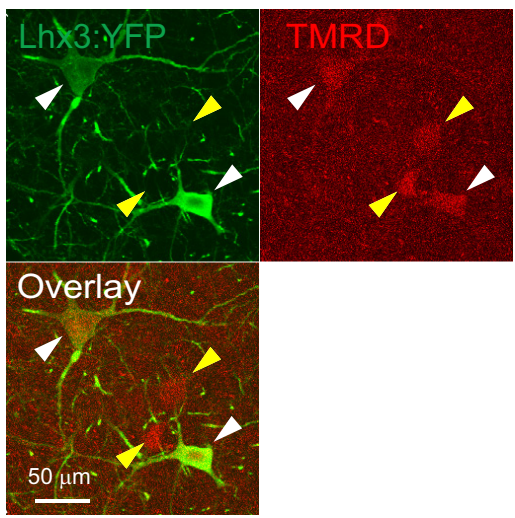

\section{E Proportion Chx10 and Lhx3 reticulospinal neurons}

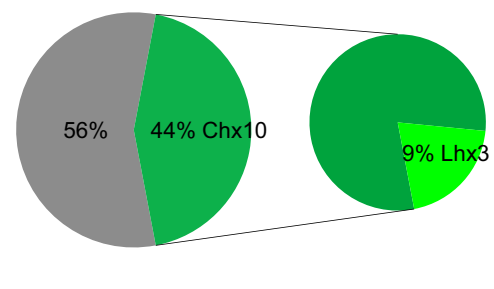

Figure 2. Lhx3 and Chx10 medRF neurons are reticulospinal neurons. A, Adult Lhx3-YFP upper lumbar spinal cord section with ChAT-positive motoneurons. Arrows indicate Lhx3-YFP axons in both ventrolateral and ventral funiculi. $\boldsymbol{B}$, Schematic showing the application of retrograde tracer TMRD at cervical level in neonatal brainstem-spinal cord preparations. C, TMRD back-labeled Lhx3-YFP medRF neurons at low (left) and high magnifications (left, dashed window). White arrowheads indicate TMRD backlabeled Lhx3-YFP neurons. Yellow arrowheads indicate Lhx3-YFP-negative TMRD-positive reticulospinal neurons. D, Proportions of fluorescent protein-TMRD cells over fluorescent protein (green) and TMRD (red) cells ( $n=3$ Lhx3-YFP and $n=3$ Chx10::GFP neonatal preparations). $\boldsymbol{E}$, Percentages of Chx10 and Lhx3 neurons among TMRD-positive reticulospinal neurons.

sections (Wilson et al., 2010). Primary antibodies included mouse or sheep anti-GFP (1:500; Biogenesis), goat anti-5HT (1:500; Immunostar), goat anti-Chx10 (1:500, Millipore Bioscience Research Reagents), goat anti-Gata2/3 (1:500; Santa Cruz Biotechnology), goat anti-Fos (1:1000; Millipore Bioscience Research Reagents), mouse anti-GAD65 or antiGAD67 (1:500), guinea-pig anti-vGluT1 (1:2500), guinea-pig antivGluT2 (1:2500), goat anti-choline acetyltransferase (ChAT, 1:100; all from Millipore Bioscience Research Reagents), and anti-Cav3.1 (1:2500; provided by Drs. Gerald Zamponi, University of Calgary, and Terry Snutch, University of British Columbia). Appropriate secondary antibodies were conjugated to Alexa 488, Alexa 555, Cy3, or Alexa 637 (1:500; Invitrogen), or rhodamine or Cy5 (1:100; Jackson ImmunoResearch).
Combined fluorescent in situ hybridization and immunohistochemistry was performed as previously described (Wilson et al., 2005).

Anterograde tracing. Biotinylated dextran amine (BDA, $10 \mathrm{kDa}, 10 \%$ in sterile water; Sigma-Aldrich) was injected in the cuneiform nucleus [CnF; $n=4$ mice; anteroposterior (AP), $-5 \mathrm{~mm}$; mediolateral (ML), $1.25 \mathrm{~mm}$; depth, $1.9 \mathrm{~mm}$ ] and the pedunculopontine nucleus (PPN; $n=2$ mice; AP, $-4.6 \mathrm{~mm}$; ML, $1.25 \mathrm{~mm}$; depth, $2.25 \mathrm{~mm}$ ) of anesthetized adult Lhx3-YFP mice, as described previously (Bretzner et al., 2008, 2010). After 1 week, mice were perfused and tissues harvested and labeled.

Retrograde tracing. tetramethylrhodamine (TMRD; Sigma-Aldrich) was applied with insect pins to the cervical level of Lhx3-YFP $(n=3)$ and Chx10::GFP $(n=3)$ neonatal superfused brainstem-spinal cord preparations. After $6-8 \mathrm{~h}$ at room temperature, the tissues were prepared for subsequent immunohistochemistry.

Images were acquired on a Zeiss LSM510 Meta confocal microscope or Zeiss Axioplan II microscope. Analyses were performed using ImageJ for cell morphology (Fig. 1) and colocalization (Figs. 2, 3, 4). The number of observations was counted for bins of $50 \mu \mathrm{m}^{2}$ for cumulative histograms (Fig. 1). All images presented are single optical sections.

Electrophysiology: patch clamp. Postnatal day 10-14 Lhx3-YFP mice were deeply anesthetized with ketamine/xylazine mix $(100 / 10 \mathrm{mg} / \mathrm{kg}$ body weight; i.p.). The animal was decapitated, and the brainstems were harvested under cold $\left(<4^{\circ} \mathrm{C}\right)$ calcium-free sucrose-substituted artificial CSF (aCSF). Transverse brainstem slices $(250 \mu \mathrm{m})$ were cut with a vibrating microtome (Vibratome 3000) and transferred to warm $\left(32-37^{\circ} \mathrm{C}\right.$ ) aCSF containing the following (in $\mathrm{mm}): 127 \mathrm{NaCl}, 1.9 \mathrm{KCl}, 1.3 \mathrm{MgCl}_{2}, 2.4 \mathrm{CaCl}_{2}$, $2.4 \mathrm{NaH}_{2} \mathrm{PO}_{4}, 26 \mathrm{NaHCO}_{3}, 10$ D-glucose, and oxygenated with $95 \% \mathrm{O}_{2}-5 \% \mathrm{CO}_{2}$ for at least $30 \mathrm{~min}$. Slices were transferred to the recording chamber and superfused with room temperature aCSF.

YFP neurons were identified under epifluorescence and visualized with infrared differential interference contrast microscopy using a Leica DMLFSA upright microscope. Wholecell patch-clamp recordings were acquired with a MultiClamp 700A amplifier, a Digidata 1322A analog-to-digital converter (Molecular Devices), and pCLAMP software (version 9 , Molecular Devices). The recording electrodes $(4-6 \mathrm{M} \Omega)$ contained an internal solution made up of the following (in mM): $140 \mathrm{KMeSO}_{4}, 10$ $\mathrm{NaCl}, 1 \mathrm{CaCl}_{2}, 10 \mathrm{HEPES}, 1$ EGTA, $3 \mathrm{Mg}$-ATP. The $\mathrm{pH}$ was adjusted to 7.2 with $\mathrm{KOH}$. The voltages presented were not corrected for junction potential, expected to be $\sim 8 \mathrm{mV}$ with these solutions.

Two-photon calcium imaging in the hemi-brainstem preparation. Postnatal day $1-5$ Chx10::eGFP mice were deeply anesthetized with ketamine/ xylazine mix (100/10 mg/kg body weight; i.p.) and decapitated. The brainstem was dissected under cold $\left(<4^{\circ} \mathrm{C}\right) \mathrm{aCSF}$, then hemisected through the midline to expose Chx10::GFP-expressing neurons in the medRF. The hemi-brainstem was then pinned, medial side up, in a customized recording chamber superfused with oxygenated aCSF. As previously described (Stosiek et al., 2003; Wilson et al., 2007), Chx10::GFP-expressing neurons were 


\section{A Excitatory Neurotransmitter Phenotype}
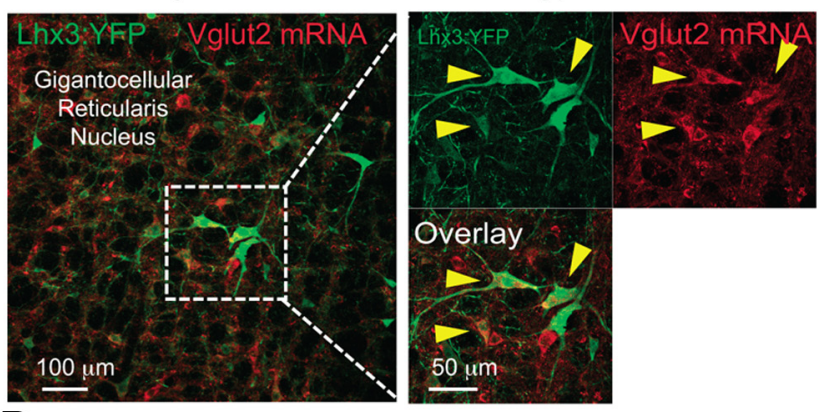

B

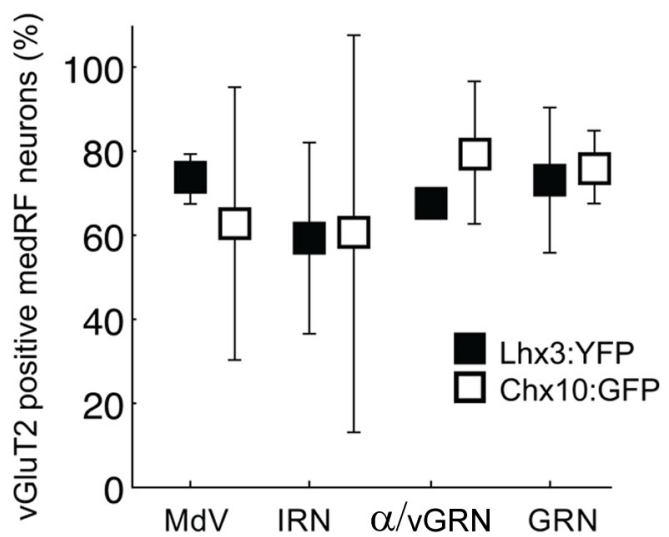

C Inhibitory Neurotransmitter Phenotype
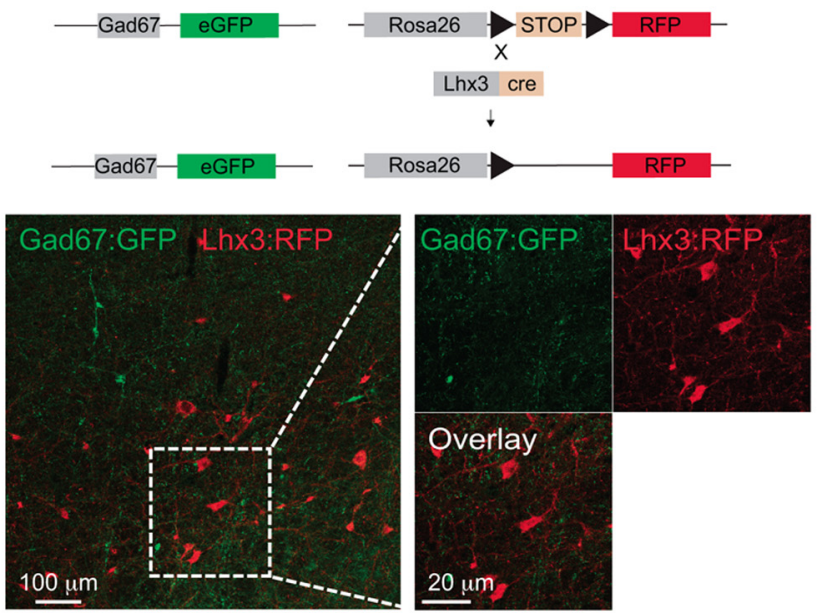

Figure 3. Lhx3 and Chx10 medRF neurons are glutamatergic. $\boldsymbol{A}$, In situ hybridization for vGluT2 mRNA and immunohistochemistry for Lhx3-YFP medRF neurons. $\boldsymbol{B}$, Mean and STD of proportions of vGluT2-expressing Lhx3-YFP (filled square) and Chx10::GFP (open square) medRF neurons across nuclei. C, Immunohistochemistry for Lhx3-RFP (red) and GAD67:GFP (green) medRF neurons showing lack of overlap.

loaded with Fluo-3 AM at $100 \mu \mathrm{M}$ (Invitrogen) using pressure injection. After 30 min recovery, brainstem neurons were visualized with a Zeiss Axioskop multiphoton microscope (Wilson et al., 2007).

GFP-expressing neurons could be readily identified, and time series of fluorescent images of calcium activity were collected with the following parameters: $1024 \times 1024$ pixel images, digital zoom $4-8$ times with $40 \times$ objective, 800 frames, $200-400 \mathrm{~ms} /$ frame. Bidirectional scanning was used to increase scan speed. Calcium transients were recorded as changes in mean pixel intensity in a defined region of interest over time and expressed as the percentage change in fluorescence divided by the baseline fluorescence $(\Delta F / F)$.
Electrodes were placed in the region of the MLR identified by surface anatomy. This region was stimulated by delivering trains of stimuli [5$150 \mu \mathrm{A}$ (mean $117 \pm 7 \mu \mathrm{A}$ ), cathodal current dependent on threshold of response, 50 pulses at $10 \mathrm{~Hz}$, pulse duration $0.2 \mathrm{~ms}$, train duration $5 \mathrm{~s}$ ] with monopolar tungsten microelectrodes (WPI), using a protocol similar to that described previously (Szokol et al., 2008). The stimulation train and a transistor-transistor logic (TTL) pulse initiated at the start of the frame scan were digitized and captured by the acquisition software to synchronize the onset and termination of stimulation to the calcium imaging traces offline.

The electrode was coated with the fluorescent dye $1,1^{\prime}$-dioctadecyl3,3,3',3'-tetramethyl-indocarbocyanine perchlorate (DiI, solution saturated in absolute alcohol; Invitrogen) to localize electrode trajectories (Szokol et al., 2008). Sections containing DiI traces were imaged and used to identify the position of the effective stimulation sites. These sites were plotted on anatomical sections of a neonatal mouse brain adapted from (Paxinos and Franklin, 2004) and the Allen Mouse Brain Atlas (http://mouse.brain-map.org/static/atlas). Data obtained using stimulation sites outside of the cuneiform/PPN were discarded.

Fos expression. The activity-dependent immediate early gene $c$-fos was assessed in adult mice walking either on a wheel for $60 \mathrm{~min}$ or on a treadmill at $20 \mathrm{~cm} / \mathrm{s}$ for $30 \mathrm{~min}$. All mice were trained to walk on either device for $4 \mathrm{~d}$, and assessed on the fifth day. Under control conditions, mice were kept in a quiet and illuminated environment for the same period. Mice were then anesthetized as above and perfused within 45-60 min of the test, and their brainstems harvested and processed for Fos immunoreactivity. The numbers of double-labeled neurons were quantified. Mice were paired-one walking with one control from the same litter at the same time of day-to remove variation based on time of day or litter, and the paired results presented normalized to the number of neurons that were Fos + in the control animals.

All figures reported and bars shown are means \pm SDs.

\section{Results}

Lhx3+ neurons are Chx10+ and are located in locomotor regions of the medRF

We first sought to determine the location of Lhx3+ neurons in the medRF. In the caudal brainstem (Fig. 1A), YFP+ neurons are distributed across the medulla including the ventral part of the medullary reticular nucleus $(\mathrm{MdV})$ and the intermediate reticular nucleus (IRN). In the rostral medulla, they are in the gigantocellular reticular nucleus (GRN) and in both ventral and $\alpha$ parts (sometimes referred to as "magnocellular") of the gigantocellular nuclei (together termed $\alpha / \mathrm{vGRN}$; Fig. $1 B$ ). Lhx3+ neurons were typically large cells, with the largest neurons located in the most rostral and dorsal parts of the medulla in the GRN and IRN, and the smallest in the most ventral and caudal medulla in the MdV and $\alpha / \mathrm{vGRN}$ (Figs. $1 D-F, 2 C$ ). The location of these neurons in known brainstem motor regions (Noga et al., 2003; Szokol et al., 2008) together with the size suggesting they may be involved in fast-conducting pathways, indicates that they may be good candidates for neurons involved in locomotion.

In the spinal cord, Lhx3-expressing interneurons (V2 neurons) are known to differentiate into V2a neurons, which are Chx10+, V2b neurons, which express Gata2/3, and a subgroup of V2c neurons, which express Gata2/3 and Sox1 (Karunaratne et al., 2002; Li et al., 2005; Al-Mosawie et al., 2007; Lundfald et al., 2007; Panayi et al., 2010). We therefore asked whether a similar genetic lineage is seen in the brainstem. Initially, we labeled Gata2/3 and Chx10 protein in early postnatal Lhx3-YFP mice, and found Gata2/3 + cells located mainly in the ventral, midline, or dorsolateral medulla [Fig. $1 H$; similar to mouse (Hafler et al., 2008; Liu et al., 2010; Crone et al., 2012) and zebrafish (Kinkhabwala et al., 2011; Koyama et al., 2011)]. None of Gata2/3 cells coexpressed YFP, suggesting that differentiation pathways in the brainstem are different from those in the spinal cord. 


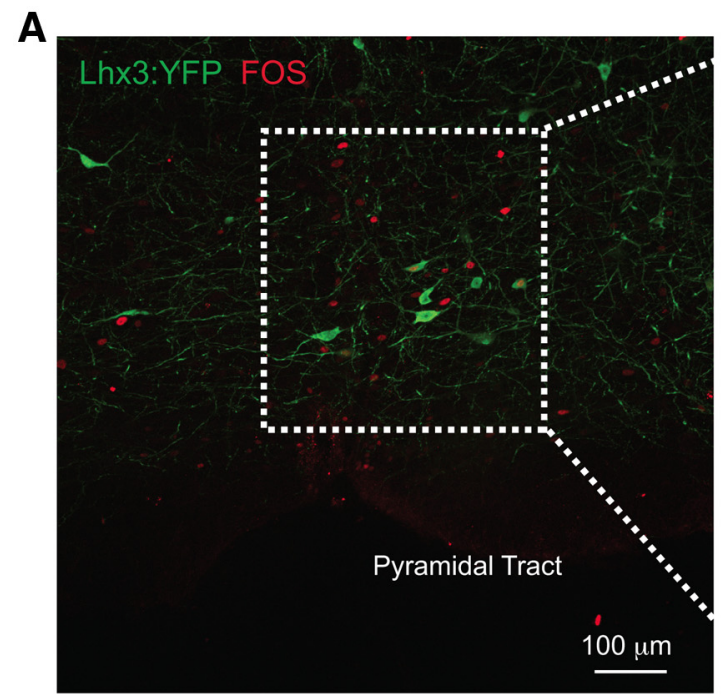

B Fos expressing YFP cells /YFP cells (\%)

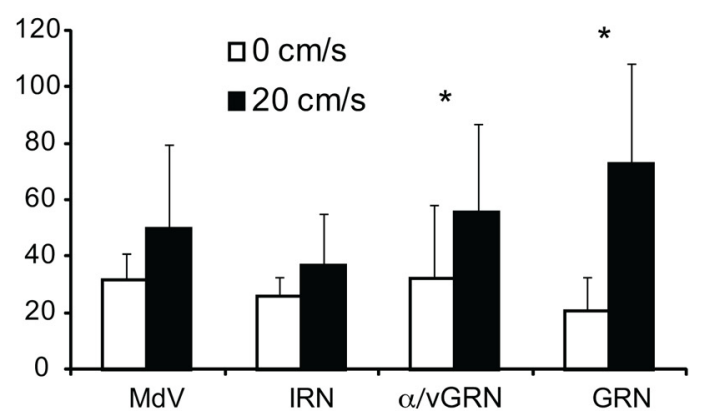

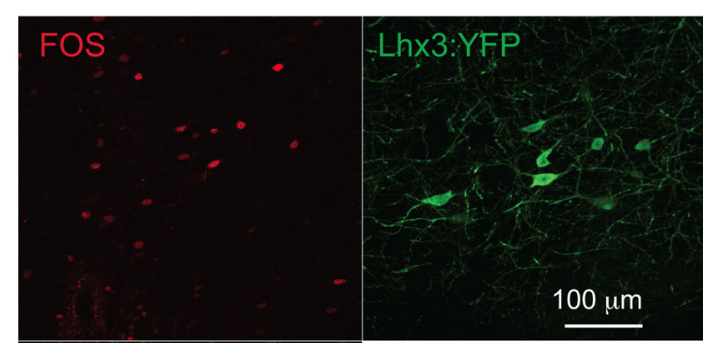

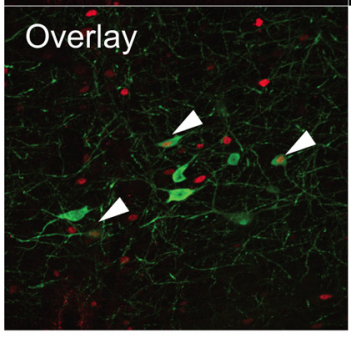

C Normalized percentage increase (\%)

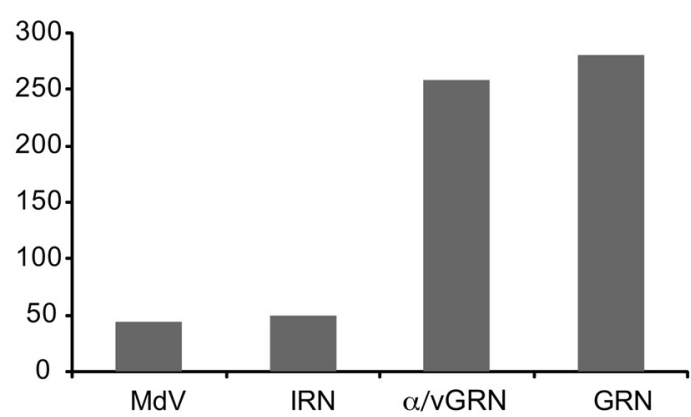

Figure 4. Genetically identified Lhx3 and Chx10 medRF neurons are active during in vivo locomotion. $A$, Fos expression in Lhx3 medRF neurons of a P21 Lhx3-YFP mouse following a locomotor task. $\boldsymbol{B}$, Proportions (mean and STD) of Fos-expressing Lhx3 and Chx10 medRF neurons from three pairs of mice kept at rest ( $n=3$, open bar) or following locomotor task ( $n=3$, filled bar). $\boldsymbol{C}$, Paired analysis showing the normalized percentage increase of Fos-expressing (Lhx3 and Chx10 together) genetically identified medRF neurons from the data illustrated in $\boldsymbol{B}$.

In contrast, Chx10-immunoreactivity was seen in YFP+ neurons in the GRN, $\alpha / \mathrm{vGRN}, \mathrm{IRN}$, and $\mathrm{MdV}$ (data not shown). Given this colocalization, we investigated the distribution of Chx10+ neurons in Chx10::eGFP mice and found the distribution and neuronal sizes to be similar to those of Lhx3+ neurons (Fig. 1C,F,G). Furthermore, in Chx10:: eGFP;Lhx3-RFP triple-transgenic mice, almost all Lhx3$\mathrm{RFP}+$ neurons (excepting a few large dorsal neurons) across the four nuclei mentioned above also expressed GFP, indicating coexpression of $\operatorname{Chx} 10$ and $\operatorname{Lhx} 3$ ( $n=3$ mice; Fig. $1 I)$. That is, Lhx3+ neurons in the medRF are Chx10+ and are found in known locomotor-related regions in the mouse (Hägglund et al., 2010). Given that Lhx3 + neurons are a subset of Chx10+ neurons, we will generically refer to these neurons as Chx10 medRF neurons.

\section{Lhx3 and Chx10 medRF neurons are reticulospinal neurons}

We next asked whether medRF Lhx3/Chx10 neurons are reticulospinal. We had noted Chx10::eGFP-labeled and Lhx3YFP-labeled axons in the white matter of the spinal cord, especially in the ventral, ventrolateral, and ventromedial funiculi, where reticulospinal axons run (Fig. 2A; Al-Mosawie et al., 2007). We applied a retrograde tracer, TMRD, to the cervical spinal cords (C2-C3) of neonatal brainstem-spinal cord preparations (Fig. $2 B, n=3$ postnatal day $10 \mathrm{Lhx} 3$-YFP and $n=3$ postnatal day 0 Chx10::GFP mice). Given that TMRD does not fill all axons (Lundfald et al., 2007), the number of neurons labeled would underestimate the number of reticulospinal neurons and the data may be skewed toward the identification of reticulospinal neurons with larger axons. Approximately 1 of 10 TMRD-labeled reticulospinal neurons were Lhx3+, whereas almost one-half were Chx10+ (Fig. 2D,E). This difference is in keeping with the incomplete recombination seen with Lhx3-cre animals, and suggests that approximately one-half of reticulospinal neurons are Chx10+. The proportion of fluorescent protein-labeled neurons that were TMRD labeled was $16 \%$ for Lhx3-YFP neurons but only $8 \%$ for Chx10::eGFP neurons. This difference likely indicates that Chx10 neurons are also involved in non-reticulospinal pathways (Crone et al., 2012). Together these data suggest that, while these neurons may be involved in systems other than reticulospinal, Lhx3+ and Chx10+ neurons form a significant component of the reticulospinal system.

\section{Lhx3 and Chx10 medRF neurons are glutamatergic}

As the fast-descending system for initiating locomotion is glutamatergic (Douglas et al., 1993), we next sought to determine whether these neurons express the glutamate transporter vGluT2 (Fig. $3 A$ ). We found that $\sim 80 \%$ of Lxh3-YFP neurons ( $n=2$ mice) and Chx10::eGFP neurons $(n=4$ mice) in the GRN express vGluT2 (Fig. 3B), indicating that they are glutamatergic. We next crossed Lhx3-RFP mice with GAD67::eGFP mice to determine whether any Lhx3 neurons were GABAergic. None of Lhx3-RFP cells were positive for GAD67::eGFP (Fig. 3C; $n=4$ mice, six sections per animal). Together with 


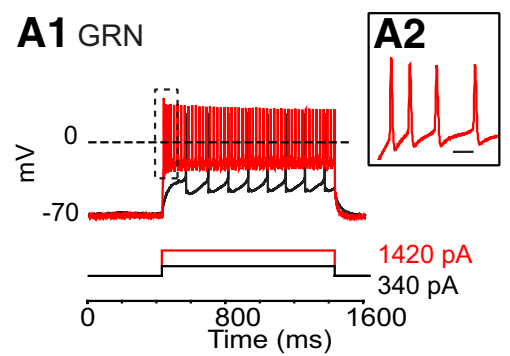

B1 GRN

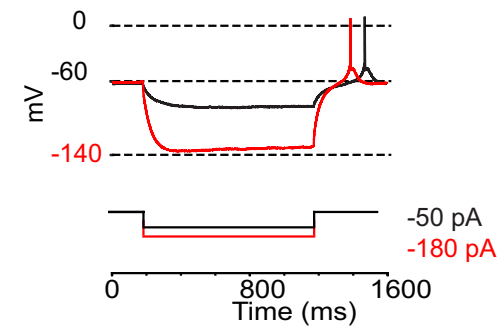

D $\alpha / v G R N$

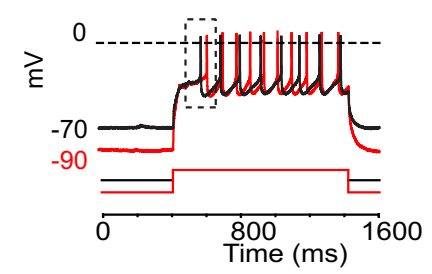

A3

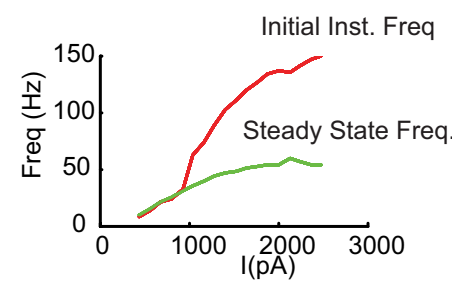

B2

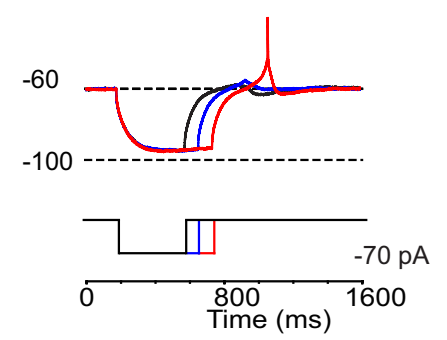

E MdV

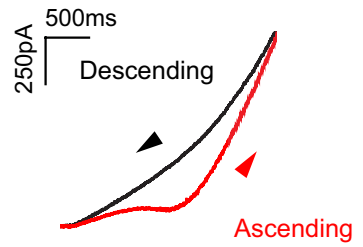

A4

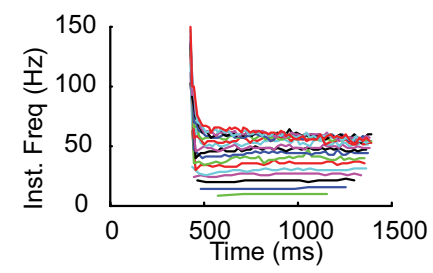

C GRN

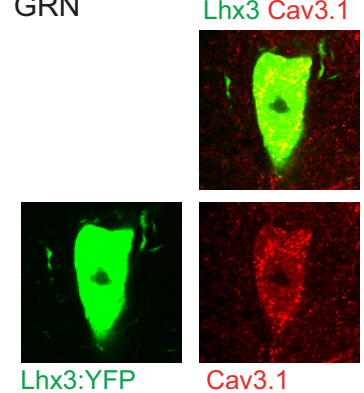

Figure 5. Electrophysiological properties of Lhx3 MedRF neurons. $\boldsymbol{A}$, Tonic repetitive firing of a Lhx3 GRN neuron at low (A1) and high (A2) time sweeps. Scale bar, 10 ms. $\boldsymbol{A 3}$, Instantaneous frequency versus current injection. $\boldsymbol{A 4}$, Instantaneous frequency versus time. Each trace represents a different amount of current injected. $\boldsymbol{B}$, Postinhibitory rebound with spike of a GRN neuron depends on the amplitude (B1) and duration (B2) of membrane hyperpolarization. $\boldsymbol{C}$, Immunolabeling for Cav3.1 onto a GRN neuron. $\boldsymbol{D}$, First-spike latency delayed following membrane hyperpolarization of an $\alpha / \mathrm{VGRN}$ neuron. $\boldsymbol{E}$, Voltage clamp demonstrates region of negative slope conductance during voltage ramp (0.03 $\mathrm{mV} / \mathrm{ms}$ for $3 \mathrm{~s})$ in a $\mathrm{MdV}$ neuron.

the expected underestimation of mRNA expression when combining fluorescent in situ hybridization (for vGluT2) with fluorescent immunohistochemistry, we conclude that medRF Lhx3 and Chx10 neurons - which belong to the same population and are reticulospinal neurons-are glutamatergic.

\section{Lhx3 and Chx10 neurons are activated during locomotion}

We next asked whether Lhx3 medRF neurons are recruited during locomotion in adult mice (Fig. 4A). The expression of $c$-fos, an activity-dependent immediate early gene, has previously been used to determine whether neurons are activated in locomotion (Dai et al., 2005; Wilson et al., 2005; Dai and Jordan, 2010a,b; Wilson et al., 2010). The proportion of fluorescent proteinpositive neurons in the GRN expressing Fos increased significantly following a locomotor task (Fig. $4 B$ ), with $\sim 80 \%$ of fluorescent protein-expressing neurons in the GRN expressing Fos following locomotion. To account for variability between litters and experiments, we paired the data, comparing control and experimental animals from the same litter. In these paired experiments, the normalized percentage increase of Fos expression was $\sim 250 \%$ in both the GRN and $\alpha /$ vGRN $(p<0.05$; Fig. $4 C$ ) compared with only $\sim 50 \%$ in the other regions. This indicates that a considerable proportion of $\mathrm{Lhx} 3 / \mathrm{Chx} 10$ brainstem neurons in the $\alpha / \mathrm{vGRN}$ and GRN are activated during locomotion in the adult mouse.
Table 1. Physiological properties of Lhx3-YFP medRF neurons (mean \pm SD)

\begin{tabular}{lccccc}
\hline & $\begin{array}{l}\text { All Lhx3 } \\
\text { neurons } \\
(n=72)\end{array}$ & $\begin{array}{l}\text { MdV } \\
(n=12)\end{array}$ & $\begin{array}{l}\text { IRN } \\
(n=8)\end{array}$ & $\begin{array}{l}\alpha / \mathrm{vGRN} \\
(n=9)\end{array}$ & $\begin{array}{l}\text { GRN } \\
(n=19)\end{array}$ \\
\hline $\begin{array}{l}\text { Resting membrane } \\
\quad \text { potential (mV) }\end{array}$ & $-50 \pm 8$ & $-51 \pm 7$ & $-49 \pm 9$ & $-50 \pm 6$ & $-53 \pm 8$ \\
Capacitance (pF) & $70 \pm 50$ & $68 \pm 28$ & $57 \pm 23$ & $70 \pm 65$ & $83 \pm 64$ \\
Input resistance (MS) & $83 \pm 58$ & $81 \pm 29$ & $59 \pm 24$ & $108 \pm 81$ & $96 \pm 76$ \\
Spike threshold (mV) & $-40 \pm 5$ & $-41 \pm 4$ & $-39 \pm 5$ & $-42 \pm 3$ & $-41 \pm 6$ \\
Spike amplitude (mV) & $71 \pm 20$ & $75 \pm 24$ & $68 \pm 15$ & $65 \pm 18$ & $77 \pm 17$ \\
Max initial frequency (Hz) & $52 \pm 36$ & $57 \pm 27$ & $47 \pm 26$ & $43 \pm 22$ & $73 \pm 50$ \\
Max steady-state & $24 \pm 11$ & $26 \pm 11$ & $23 \pm 8$ & $23 \pm 5$ & $32 \pm 14$ \\
$\quad$ frequency (Hz) & & & & & \\
AHP duration (ms) & $238 \pm 115$ & $282 \pm 142$ & $256 \pm 112$ & $293 \pm 113$ & $211 \pm 102$ \\
$f-I$ gain (Hz/100 pA) & $9 \pm 8$ & $10 \pm 10$ & $8 \pm 2$ & $7 \pm 3$ & $11 \pm 8$ \\
\hline
\end{tabular}

\section{Chx10 medRF neurons have diverse}

electrophysiological properties

Because the physiological properties of neurons are critical to the function of the networks in which they are involved (HarrisWarrick, 1993; Marder and Bucher, 2007), we compared properties of YFP + neurons of different nuclei in brainstem slices of postnatal day 10-14 Lhx3-YFP mice (Fig. 5, Table 1). Unfortunately, we were unable to successfully patch clamp healthy neurons in slices following the long incubation times needed for retrograde labeling, so neurons were identified based on their location and expression of fluorescent proteins. To ensure inclu- 
Table 2. Proportion of Lhx3-YFP brainstem neurons

\begin{tabular}{llllll}
\hline & All Lhx3 & & & & \\
& neurons & MdV & IRN & $\alpha /$ GGN & GRN \\
\hline Tonic firing & $92 \%(66 / 72)$ & $100 \%(12 / 12)$ & $100 \%(8 / 8)$ & $89 \%(8 / 9)$ & $80 \%(15 / 19)$ \\
Doublet & $22 \%(16 / 72)$ & $23 \%(3 / 13)$ & $43 \%(3 / 7)$ & $10 \%(1 / 10)$ & $25 \%(5 / 20)$ \\
Sag & $60 \%(39 / 66)$ & $64 \%(7 / 11)$ & $75 \%(6 / 8)$ & $67 \%(6 / 9)$ & $42 \%(7 / 17)$ \\
PIR & $43 \%(27 / 63)$ & $36 \%(4 / 11)$ & $37 \%(3 / 8)$ & $33 \%(3 / 9)$ & $59 \%(10 / 17)$ \\
$\begin{array}{l}\text { Delayed first-spike } \\
\quad \text { latency }\left(I_{A}\right)\end{array}$ & $50 \%(17 / 34)$ & $45 \%(5 / 11)$ & $72 \%(5 / 7)$ & $67 \%(2 / 3)$ & $28 \%(2 / 7)$ \\
$\begin{array}{c}\text { Region of negative } \\
\quad \text { slope conductance }\end{array}$ & $44 \%(24 / 55)$ & $88 \%(7 / 8)$ & $28 \%(2 / 7)$ & $50 \%(4 / 8)$ & $33 \%(5 / 15)$ \\
\hline
\end{tabular}
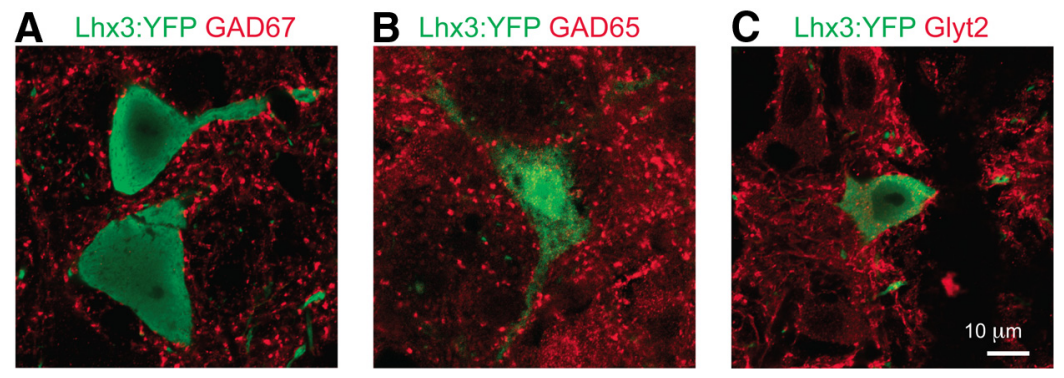

Figure 6. Inhibitory inputs to Lhx3-YFP MedRF neurons. $\boldsymbol{A}-\boldsymbol{C}, \mathrm{GAD67}(\boldsymbol{A}), \mathrm{GAD65}(\boldsymbol{B})$, and GlyT2 (C) boutons in apposition to Lhx3-YFP medRF neurons.

sion of healthy neurons only, neurons with peak-to-peak action potential amplitudes $>60 \mathrm{mV}$ were used in this analysis $(n=72$ neurons). The resting potentials and input resistances of neurons across the four nuclei were similar, but as expected the larger cells of the GRN (Fig. 1D) tended to have higher whole-cell capacitances (Table 1).

Given that tonic descending commands can activate spinal locomotor circuits, we determined whether Chx10 medRF neurons could sustain repetitive firing. Injections of current led to sustained tonic repetitive firing in 66 of 72 (92\%) neurons across the four nuclei (Fig. 5A, Table 2). The input-output relation, as assessed by frequency-current $(f-I)$ gain, was similar across the four nuclei $(9 \pm 1 \mathrm{~Hz} / 100 \mathrm{pA})$, although 1 of 9 neurons in the $\alpha /$ vGRN had a slope $>10 \mathrm{~Hz} / 100 \mathrm{pA}$ (Fig. 5A3). Spike frequency adaptation was seen in neurons of all nuclei, particularly with the higher current injections (Fig. 5A4; 38 of 72 neurons had ratio of second to last instantaneous frequencies $>1.5$ ). There was no difference in afterhyperpolarization (AHP) duration (Table 1), although only neurons within the GRN (3 of 15) had AHP durations $<110 \mathrm{~ms}$ and none of the neurons in the GRN (as opposed to each of the other nuclei) had AHP durations $>400 \mathrm{~ms}$. Together these data indicate that most neurons in medRF locomotor regions could repetitively fire in a steeply graded fashion, and could sustain this firing. Reticulospinal neurons would be a subset of those recorded and, given the ubiquity of these findings, would be expected to have these same properties.

We had also noticed that some neurons in each nucleus fired with doublets at the onset of the higher-magnitude step depolarizations (Fig. 5A2,A3; 16 of 72 neurons had ratio of first to second instantaneous frequencies $>1.5$ ). The maximum initial instantaneous frequency was similar across all four nuclei, but neurons in the $\alpha /$ vGRN and IRN never had doublets $>100 \mathrm{~Hz}$, and only 1 of 12 in MdV had a doublet $>100 \mathrm{~Hz}$. This contrasts with the GRN, in which 4 of 19 had doublets between 110 and $200 \mathrm{~Hz}$. We next asked whether postinhibitory rebound (PIR) could account for the doublets. PIR ensures rapid firing of neurons following release of inhibition, and is prominent in some neurons involved in motor circuits (Perkel and Mulloney, 1974; Willows, 1980; Miller and Selverston, 1982). As with the high-frequency initial doublets, PIR was found most commonly in GRN neurons and was dependent on the amplitude and duration of the preceding membrane hyperpolarization (10 of 17 neurons; Fig. 5B1,B2), which is consistent with it being produced by a $\mathrm{Ca}_{\mathrm{V}} 3$ (T-type) current, and consistent with $\mathrm{Ca}_{\mathrm{V}} 3.1$ expression (Fig. 5C). As GAD65-IR, GAD67-IR, and GlyT2-IR boutons are found in close apposition to these neurons (Fig. 6), it is possible that during circuit operation, inhibition could prime GRN neurons for rapid-onset firing.

Some central bursting neurons coexpress A-type and $\mathrm{Ca}_{\mathrm{V}} 3$ type currents (Molineux et al., 2005; Anderson et al., 2010), and together provide a mechanism by which PIR can be modulated (Harris-Warrick et al., 1995a,b). We therefore asked whether A-type currents, which lead to a delay to first spike following hyperpolarization, are present in Chx10 medRF neurons. A delay to first spike, dependent on magnitude of hyperpolarization, was most commonly seen in $\alpha / \mathrm{vGRN}, \mathrm{MdV}$, and IRN neurons, and was conspicuously absent in GRN neurons, the latter group being more likely to express T-type currents (Fig. 5, compare $D, B 1)$. Thus, there was little evidence of coexpression of A-type and T-type currents in YFP+ neurons.

Finally, neurons involved in motor circuits may express persistent conductances $\left(\mathrm{Na}^{+}\right.$and/or $\left.\mathrm{Ca}^{2+}\right)$ to maintain firing (Miles et al., 2005) and/or amplify synaptic input (Hultborn et al., 2004). Slow ramp depolarizations in voltage-clamp experiments revealed that neurons, particularly in the $\mathrm{MdV}(88 \%)$, had regions of negative slope conductance (Fig. 5E; Schwindt and Crill, 1977). This contrasts with only $37 \%$ of neurons in the other nuclei (Table 2, Fisher's exact test $p=0.06$ ) and suggests that $\mathrm{MdV}$ neurons in particular may have the capacity to fire in a sustained manner with minimal synaptic input, and/or to significantly amplify their inputs.

In summary, although some electrophysiological properties may differ in incidence between the nuclei, we have found no clear electrophysiological signatures of $\mathrm{Lhx} 3 / \mathrm{Chx} 10$ neurons that correspond to the particular nuclei of the medRF. The electrophysiological properties of these neurons are heterogeneous across these four nuclei.

\section{Lhx3 and Chx10 medRF neurons receive inputs from the MLR}

If Chx10 medRF neurons mediate a descending command for locomotion, they should receive input from the MLR, a region known to initiate locomotion in various species (Shik et al., 1966; Orlovski1̆, 1970; Steeves and Jordan, 1984; Garcia-Rill et al., 1987; Mori, 1987; Takakusaki et al., 2003a). The MLR corresponds to the $\mathrm{CnF}$, with the adjacent PPN also implicated in motor control (Garcia-Rill et al., 1985; 1990; Milner and Mogenson, 1988; Jordan, 1998; Takakusaki et al., 2003a, b). Two weeks following stereotactic injection of an anterograde tracer, $\mathrm{BDA}$, into the $\mathrm{CnF}$ and PPN $(n=6)$ of adult Lhx3-YFP mice (Fig. $7 A)$, BDA-labeled axon terminals were found in close proximity to Lhx3-YFP brainstem neurons, particularly in the rostral medRF in the $\alpha / \mathrm{vGRN}$ (Fig. $7 \mathrm{~B}, \mathrm{C}$ ), and some terminals in the GRN. These data support anatomically that neurons in both the $\alpha / \mathrm{vGRN}$ and GRN receive MLR inputs.

To determine whether there is functional connectivity, we used multiphoton microscopy (Fig. $8 A$ ) for calcium imaging of Chx10 

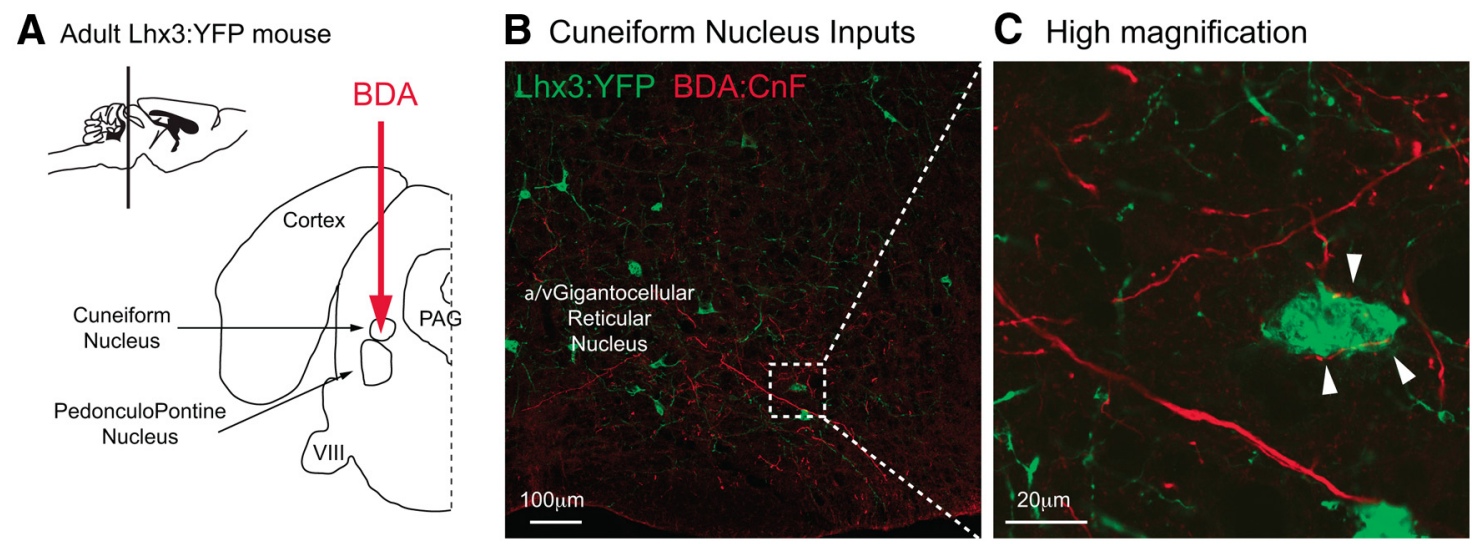

Figure 7. MLR projections to Lhx3-YFP medRF neurons. $\boldsymbol{A}$, Schematic illustrating the injection site of an anterograde tracer, BDA, within the cuneiform nucleus (MLR) in adult Lhx3-YFP mice. $\boldsymbol{B}$, $\boldsymbol{C}$, BDA-filled axonal terminals in close proximity to Lhx3-YFP + neurons located within the $\alpha / v G R N$ at low $(\boldsymbol{B})$ and high $(\boldsymbol{C}$, from the dashed window in $\boldsymbol{B})$ magnification.

neurons while stimulating the region of the MLR ( $\mathrm{CnF}$ and PPN). We detected calcium transients in $21 \%$ of Chx10::GFP neurons in the GRN and $\alpha / \mathrm{vGRN}$ in response to MLR stimulation $(n=30 / 144$ cells, $n=13$ stimulating sites, 7 of which were identified by histology; Fig. $8 B$ ). The responses were not uniform: individual stimulation sites led to calcium transients in some Chx10::GFP neurons with no responses in others (Fig. 8D2). Stimulation in 5 of 7 identified sites (Fig. $8 B$, blue dots) led to increases in calcium transients in 23 of the 30 neurons (Fig. 8D1,D2). Stimulation in the other two sites (Fig. $8 B$, red dots) led to either decreases or poststimulation (i.e. after cessation of stimulation) increases in calcium transients in the other seven neurons (Fig. 8D3). These poststimulation increases in calcium transients could result from PIR (Fig. 5B). In general, stimulation sites in the dorsal area in the region of the $\mathrm{CnF}$ led to increases in calcium transients in Chx10::GFP neurons, while stimulation sites located in the region of the PPN evoked a mixture of decreases and increases in calcium transients in these neurons (Fig. 8D3). Taking the anatomical and physiological data together, we conclude that neurons in the region of the MLR project to and excite Chx10+ neurons in the medRF, thus supporting their potential role in locomotor circuits.

\section{Discussion}

While recent studies have furthered our understanding of spinal interneuronal networks that produce locomotor movements, little is known about the neurons that mediate the descending motor commands that initiate and modulate mammalian walking (Jordan et al., 2008). We have shown that Lhx3/Chx10-expressing neurons in the medRF are large glutamatergic neurons, a subset of which constitutes a subset of reticulospinal pathways. These neurons are activated during locomotion in adult mice, and receive functional synaptic inputs from the MLR, a supraspinal structure involved in initiation and maintenance of locomotion. Together, these data support a possible role for Lhx3/Chx10-expressing medRF neurons in mammalian brainstem locomotor networks.

\section{Brainstem versus spinal cord Lhx 3 and Chx10 neurons}

Our data demonstrate a difference in differentiation between Lhx3expressing neurons in the brainstem compared with the spinal cord. During spinal cord development, cells from the p2 progenitor domain express a combination of transcription factors, including Lhx3 (Zhou et al., 2000; Karunaratne et al., 2002; Li et al., 2005). These Lhx3 + V2 cells diversify into several distinct interneuronal populations: Chx10-expressing glutamatergic V2a and Gata2/3-expressing GABA/glycinergic V2b-c interneurons (Karunaratne et al., 2002; Li et al., 2005; Al-Mosawie et al., 2007; Lundfald et al., 2007; Batista et al., 2008). In contrast, in the medulla, based on their size, location, and glutamatergic phenotype, YFP + neurons in Lhx3-YFP animals seem to be a subset of GFP+ neurons in Chx10::eGFP mice. Furthermore, we found no Lhx3+/Gata3 + double-labeled cells in the medRF. Also, parallel to findings in chick (Cepeda-Nieto et al., 2005), all but a very few large Lhx3-expressing neurons in the dorsal aspect of the GRN expressed Chx10. The fact that the numbers of Lhx3-YFP neurons were lower than those of Chx10::eGFP neurons likely resulted from incomplete recombination using $\mathrm{Lhx} 3^{\mathrm{cre} /+}$ crossed with this thyl-fs-YFP reporter mouse (Al-Mosawie et al., 2007). This is not the first example in which neurons that developmentally express the same transcription factors in the brainstem and spinal cord differentiate into different subpopulations in each of these structures. For example, the majority of neurons expressing Dbxl in the spinal cord are inhibitory interneurons (Pierani et al., 2001; Lanuza et al., 2004), whereas in the brainstem, Dbx1expressing neurons are glutamatergic (Bouvier et al., 2010; Gray et al., 2010). In summary, our data support that, in contrast to the spinal cord, the majority of Lhx3 + neurons in the medRF differentiate into glutamatergic Chx10+ neurons.

\section{Possible role of Chx10 medRF neurons in the descending control of locomotion}

Reticulospinal neurons play a central role in locomotion, as demonstrated in Xenopus tadpoles (Roberts et al., 2008), fish (Brocard and Dubuc, 2003; Kinkhabwala et al., 2011; Koyama et al., 2011; Kimura et al., 2013), birds (Sholomenko et al., 1991), and mammals (GarciaRill and Skinner, 1987a; Zaporozhets et al., 2006; Hägglund et al., 2010). These neurons are activated by higher locomotor centers, such as the MLR (Noga et al., 2003), the cerebellar locomotor region (Homma et al., 1995; Mori et al., 1998), and subthalamic locomotor region/lateral hypothalamus (Sinnamon and Stopford, 1987), and are thus likely responsible for integrating these higher locomotor signals. In turn, they activate spinal locomotor networks (Steeves and Jordan, 1984; Shefchyk and Jordan, 1985; Garcia-Rill and Skinner, 1987a,b; Noga et al., 1988, 1991, 2003; Marlinsky and Voitenko, 1991). To determine whether a population of neurons in the reticular formation mediate the descending command for locomotion, they should meet the following criteria: (1) they should be reticulospinal; (2) they should have a glutamatergic transmitter phenotype; (3) they should be able to sustain repetitive firing; (4) they should be activated in locomotion; (5) they should receive inputs from higher locomotor centers; and at least one of: (6) their selective activation should produce sustained locomotion (sufficiency); and/or (7) their selective inhibition should inhibit locomotion (ne- 
A

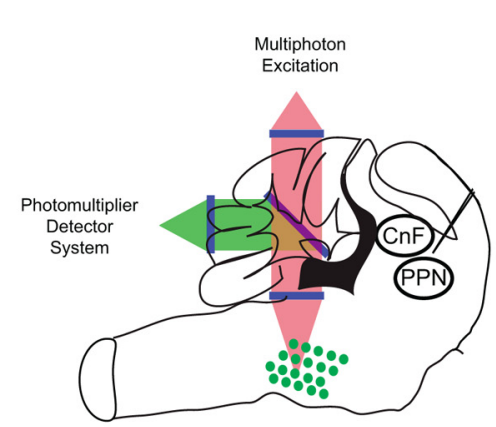

D1

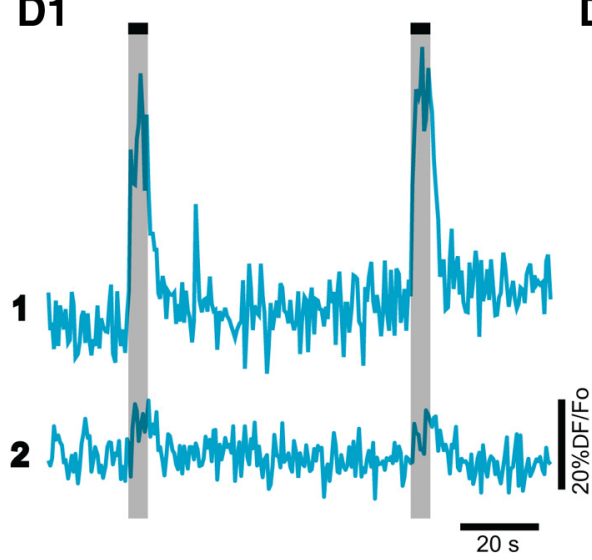

E

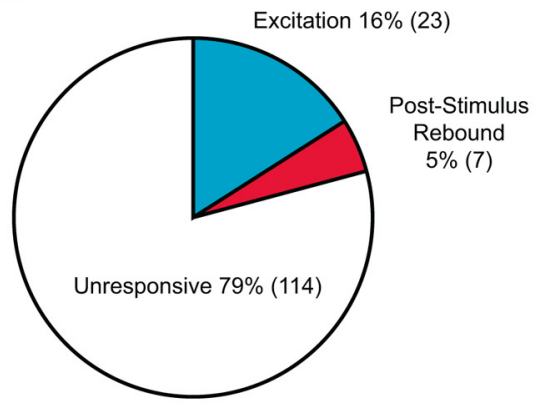

B

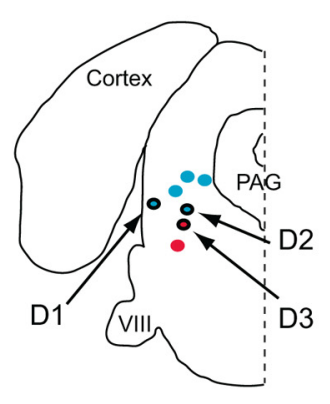

C Cell Identifcation (site D1)

Chx10:GFP

(ex 900nm, em BP485)

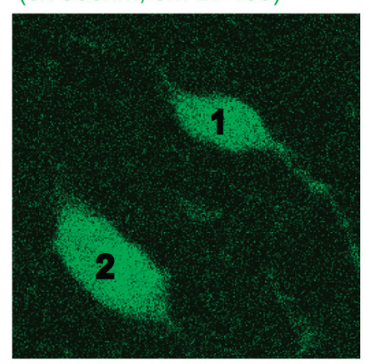

Fluo3

(ex 800nm, em LP515)

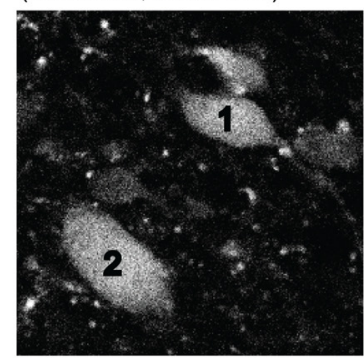

D2

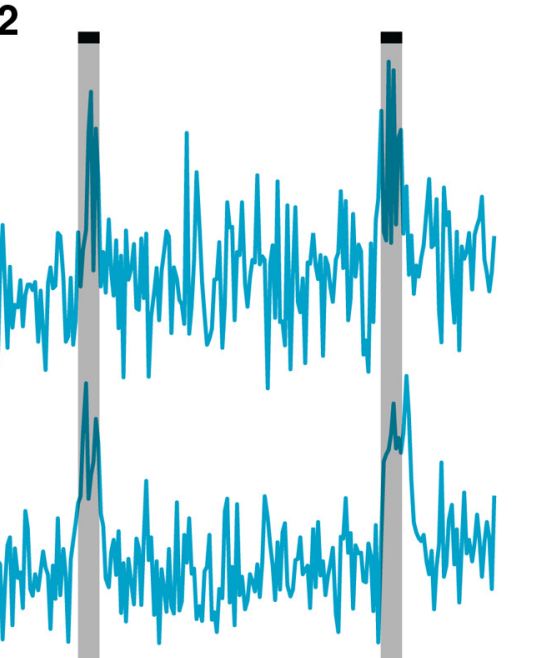

D3
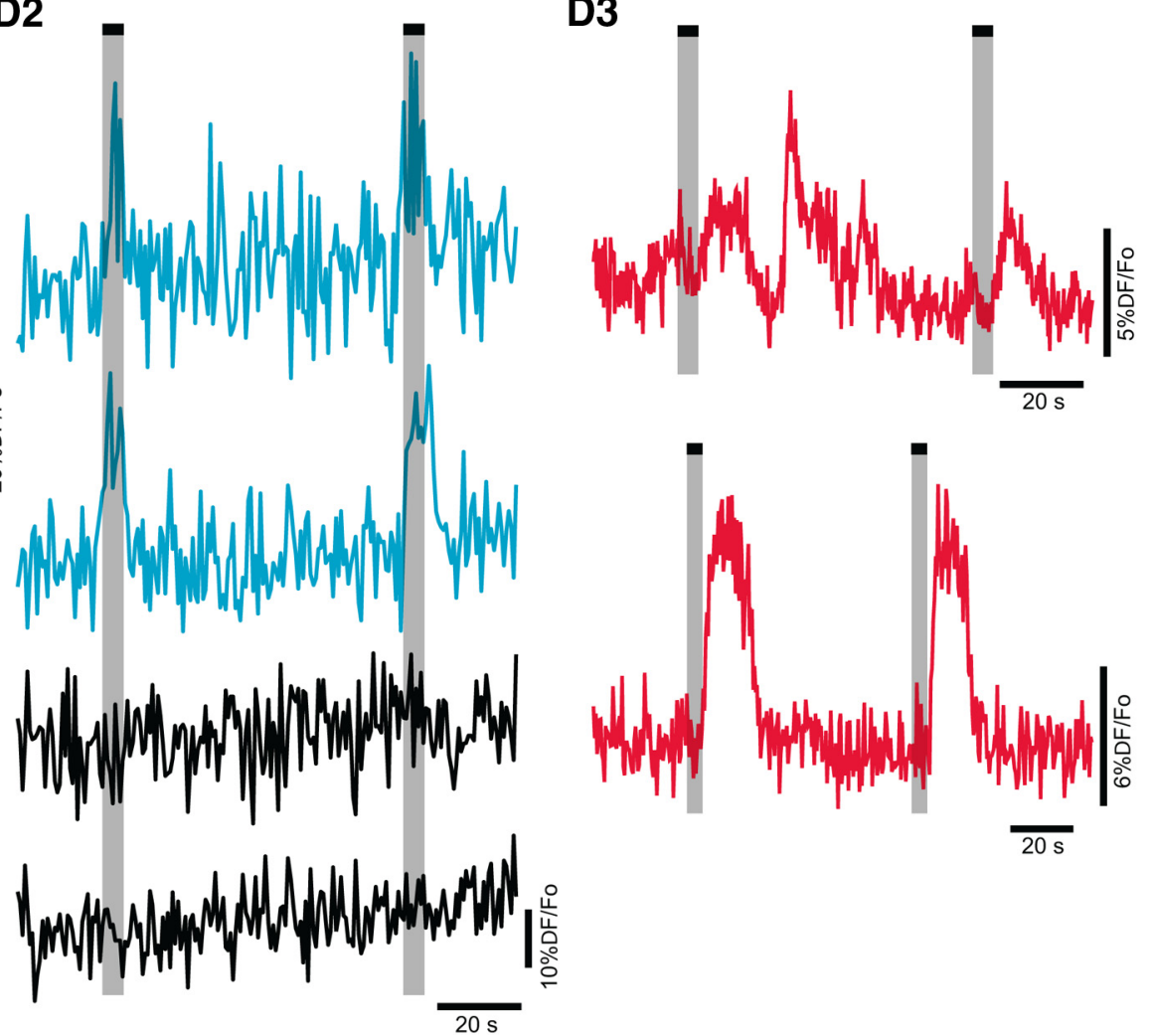
. 
monosynaptic connectivity from the MLR to reticulospinal neurons in various species, including cat, newt, lamprey, and salamander (Iwakiri et al., 1995; Bar-Gad et al., 1999; Brocard and Dubuc, 2003; Kagan and Shik, 2004). While our data do not define the anatomical correlates of the MLR, it is interesting that, as opposed to the few deeper stimulation sites, the more dorsal sites (in the region of the CnF nucleus) led to activation of Chx10 neurons. This is in agreement with previous studies in cat, which showed that stimulation of the CnF and dorsal PPN, through their effects on reticulospinal neurons, depolarized lumbar motoneurons, leading to increased muscle tone and locomotion, whereas stimulation of the ventral PPN led to tonic inhibition (Takakusaki et al., 1989, 2003b; Habaguchi et al., 2002). Excitation of Chx10 medRF neurons by MLR stimulation supports their potential role in mediating locomotor commands, and fulfills the fifth criterion above.

The last two criteria have proven to be much more difficult to demonstrate. Although a recent optogenetic study has demonstrated the critical role of Chx10 hindbrain neurons for swimming in the zebrafish (Kimura et al., 2013), photostimulation of glutamatergic hindbrain neurons in the mouse evoked only a few steps of locomotor-like activity (Hägglund et al., 2010). In addition, our attempts to selectively inactivate (using allatostatin receptor expression) or activate (using selective TRPV1 receptor or channelrhodospin2 expression) brainstem Lhx3 neurons failed to consistently alter or drive locomotor activity (data not shown). This may be because Lhx3 is expressed in heterogeneous neurons. Even the reticulospinal subpopulation of Lhx3 neurons may be mixed, with some involved in activating movement, and others involved in inactivating movement (Takakusaki et al., 2003a). Thus we cannot definitively state whether these neurons, or subpopulations of these neurons, are either necessary or sufficient for locomotion. However, by fulfilling at least five of the seven criteria above, our data do support the idea that Lhx3/Chx10 medRF neurons in the GRN and $\alpha / \mathrm{vGRN}$ are candidates for mediators of the descending control of mammalian locomotion.

\section{Role of Chx10 medRF neurons in other motor functions}

Chx10 medRF neurons are found in four discrete nuclei, each of which likely serves different functions. We have suggested that Chx10 neurons of the GRN and $\alpha / \mathrm{vGRN}$ are involved in locomotor control. In contrast, we have shown that MdV neurons, which may be involved in licking behavior (Travers et al., 1997), have some distinct electrophysiological properties. It is possible that $\mathrm{Lhx3}$ / Chx10 medRF neurons could be involved in integrating supraspinal and spinal inputs to adapt and coordinate motor behaviors to environmental and intrinsic constraints (Prentice and Drew, 2001; Drew et al., 2004; Schepens and Drew, 2004, 2006). Recently, Chx10 brainstem neurons have been found to be important in the control of respiration: genetic deletion of Chx10 neurons led to irregular and low breathing frequency in isolated preparations and whole animals (Crone et al., 2012). Given that stimulation of the MLR, in addition to initiating locomotion, increases respiratory frequency (Waldrop and Iwamoto, 2006; Gariépy et al., 2012) and that locomotion modulates respiration through brainstem networks in the lamprey (Gravel et al., 2007), it is possible that Chx10 medRF neurons are involved in adjusting ventilation to motor output during locomotion. Such coupling of multiple motor circuits could adjust motor behavior to environmental constraints.

Possible role of Chx10 neurons in recovery of motor function It has recently been shown that strategies that improve reticulospinal axon regeneration after spinal cord injury can lead to a worsened functional outcome (Lu et al., 2012). This, together with the known roles of glutamatergic reticulospinal pathways in initiating locomotion (Hägglund et al., 2010) and their control over propriospinal (Zaporozhets et al., 2006) and spinal commissural neurons (Szokol et al., 2011), illustrates the importance of understanding the functions of identified reticulospinal neurons. Given their inputs from the MLR, it is possible that Chx10 reticulospinal pathways may contribute to reorganization after spinal cord injury. Moreover, given the convergence of diverse supraspinal, including cortical, inputs onto reticulospinal neurons (Drew et al., 2002; Jankowska and Edgley, 2006; Baker, 2011; Zaaimi et al., 2012), they may also play a key role in rerouting descending motor commands after brain injury (Jankowska et al., 2005). Furthermore, recent trials of deep brain stimulation in the region of the dorsal mesopontine tegmentum (the region of the CnF and PPN) have shown some improvement in gait in people with Parkinson's disease (Stefani et al., 2007; Pereira et al., 2008). This improvement could be mediated via reticulospinal pathways, possibly Chx10 medRF neurons.

In the current study, we have identified reticulospinal neurons that may be involved in locomotor control. Such definition is necessary for the development of new strategies aimed at motor functional restoration in people with injuries and diseases affecting the CNS.

\section{References}

Al-Mosawie A, Wilson JM, Brownstone RM (2007) Heterogeneity of V2derived interneurons in the adult mouse spinal cord. Eur J Neurosci 26: 3003-3015. CrossRef Medline

Anderson D, Mehaffey WH, Iftinca M, Rehak R, Engbers JD, Hameed S, Zamponi GW, Turner RW (2010) Regulation of neuronal activity by Cav3-Kv4 channel signaling complexes. Nat Neurosci 13:333-337. CrossRef Medline

Baker SN (2011) The primate reticulospinal tract, hand function and functional recovery. J Physiol 589:5603-5612. CrossRef Medline

Bar-Gad I, Kagan I, Shik ML (1999) Behavior of hindbrain neurons during the transition from rest to evoked locomotion in a newt. Prog Brain Res 123:285-294. CrossRef Medline

Batista MF, Jacobstein J, Lewis KE (2008) Zebrafish V2 cells develop into excitatory CiD and Notch signalling dependent inhibitory VeLD interneurons. Dev Biol 322:263-275. CrossRef Medline

Bouvier J, Thoby-Brisson M, Renier N, Dubreuil V, Ericson J, Champagnat J, Pierani A, Chédotal A, Fortin G (2010) Hindbrain interneurons and axon guidance signaling critical for breathing. Nat Neurosci 13:1066-1074. CrossRef Medline

Bretzner F, Drew T (2005) Contribution of the motor cortex to the structure and the timing of hindlimb locomotion in the cat: a microstimulation study. J Neurophysiol 94:657-672. CrossRef Medline

Bretzner F, Liu J, Currie E, Roskams AJ, Tetzlaff W (2008) Undesired effects of a combinatorial treatment for spinal cord injury-transplantation of olfactory ensheathing cells and BDNF infusion to the red nucleus. Eur J Neurosci 28:1795-1807. CrossRef Medline

Bretzner F, Plemel JR, Liu J, Richter M, Roskams AJ, Tetzlaff W (2010) Combination of olfactory ensheathing cells with local versus systemic cAMP treatment after a cervical rubrospinal tract injury. J Neurosci Res 88:2833-2846. CrossRef Medline

Brocard F, Dubuc R (2003) Differential contribution of reticulospinal cells to the control of locomotion induced by the mesencephalic locomotor region. J Neurophysiol 90:1714-1727. CrossRef Medline

Brownstone RM, Bui TV (2010) Spinal interneurons providing input to the final common path during locomotion. Prog Brain Res 187:81-95. CrossRef Medline

Cepeda-Nieto AC, Pfaff SL, Varela-Echavarría A (2005) Homeodomain transcription factors in the development of subsets of hindbrain reticulospinal neurons. Mol Cell Neurosci 28:30-41. CrossRef Medline

Crone SA, Viemari JC, Droho S, Mrejeru A, Ramirez JM, Sharma K (2012) Irregular breathing in mice following genetic ablation of $\mathrm{V} 2 \mathrm{a}$ neurons. J Neurosci 32:7895-7906. CrossRef Medline

Dai X, Noga BR, Douglas JR, Jordan LM (2005) Localization of spinal neurons activated during locomotion using the c-fos immunohistochemical method. J Neurophysiol 93:3442-3452. CrossRef Medline 
Dai Y, Jordan LM (2010a) Multiple patterns and components of persistent inward current with serotonergic modulation in locomotor activityrelated neurons in Cfos-EGFP mice. J Neurophysiol 103:1712-1727. CrossRef Medline

Dai Y, Jordan LM (2010b) Multiple effects of serotonin and acetylcholine on hyperpolarization-activated inward current in locomotor activity-related neurons in Cfos-EGFP mice. J Neurophysiol 104:366-381. CrossRef Medline

Degtyarenko AM, Simon ES, Burke RE (1998) Locomotor modulation of disynaptic EPSPs from the mesencephalic locomotor region in cat motoneurons. J Neurophysiol 80:3284-3296. Medline

Deliagina TG, Zelenin PV, Orlovsky GN (2002) Encoding and decoding of reticulospinal commands. Brain Res Brain Res Rev 40:166-177. CrossRef Medline

Dougherty KJ, Kiehn O (2010) Firing and cellular properties of V2a interneurons in the rodent spinal cord. J Neurosci 30:24-37. CrossRef Medline

Douglas JR, Noga BR, Dai X, Jordan LM (1993) The effects of intrathecal administration of excitatory amino acid agonists and antagonists on the initiation of locomotion in the adult cat. J Neurosci 13:990-1000. Medline

Drew T, Jiang W, Widajewicz W (2002) Contributions of the motor cortex to the control of the hindlimbs during locomotion in the cat. Brain Res Brain Res Rev 40:178-191. CrossRef Medline

Drew T, Prentice S, Schepens B (2004) Cortical and brainstem control of locomotion. Prog Brain Res 143:251-261. CrossRef Medline

Dubuc R, Brocard F, Antri M, Fénelon K, Gariépy JF, Smetana R, Ménard A, Le Ray D, Viana Di Prisco G, Pearlstein E, Sirota MG, Derjean D, St-Pierre M, Zielinski B, Auclair F, Veilleux D (2008) Initiation of locomotion in lampreys. Brain Res Rev 57:172-182. CrossRef Medline

Feng G, Mellor RH, Bernstein M, Keller-Peck C, Nguyen QT, Wallace M, Nerbonne JM, Lichtman JW, Sanes JR (2000) Imaging neuronal subsets in transgenic mice expressing multiple spectral variants of GFP. Neuron 28:41-51. CrossRef Medline

Garcia-Rill E, Skinner RD (1987a) The mesencephalic locomotor region. I. Activation of a medullary projection site. Brain Res 411:1-12. CrossRef Medline

Garcia-Rill E, Skinner RD (1987b) The mesencephalic locomotor region. II. Projections to reticulospinal neurons. Brain Res 411:13-20. CrossRef Medline

Garcia-Rill E, Skinner RD, Fitzgerald JA (1985) Chemical activation of the mesencephalic locomotor region. Brain Res 330:43-54. CrossRef Medline

Garcia-Rill E, Houser CR, Skinner RD, Smith W, Woodward DJ (1987) Locomotion-inducing sites in the vicinity of the pedunculopontine nucleus. Brain Res Bull 18:731-738. CrossRef Medline

Garcia-Rill E, Kinjo N, Atsuta Y, Ishikawa Y, Webber M, Skinner RD (1990) Posterior midbrain-induced locomotion. Brain Res Bull 24:499-508. CrossRef Medline

Gariépy JF, Missaghi K, Chevallier S, Chartré S, Robert M, Auclair F, Lund JP, Dubuc R (2012) Specific neural substrate linking respiration to locomotion. Proc Natl Acad Sci U S A 109:E84-E92. CrossRef Medline

Gong S, Zheng C, Doughty ML, Losos K, Didkovsky N, Schambra UB, Nowak NJ, Joyner A, Leblanc G, Hatten ME, Heintz N (2003) A gene expression atlas of the central nervous system based on bacterial artificial chromosomes. Nature 425:917-925. CrossRef Medline

Goulding M (2009) Circuits controlling vertebrate locomotion: moving in a new direction. Nat Rev Neurosci 10:507-518. CrossRef Medline

Gravel J, Brocard F, Gariépy JF, Lund JP, Dubuc R (2007) Modulation of respiratory activity by locomotion in lampreys. Neuroscience 144:1120-1132. CrossRef Medline

Gray PA, Hayes JA, Ling GY, Llona I, Tupal S, Picardo MC, Ross SE, Hirata T, Corbin JG, Eugenín J, Del Negro CA (2010) Developmental origin of preBotzinger complex respiratory neurons. J neurosci 30:14883-14895. CrossRef Medline

Habaguchi T, Takakusaki K, Saitoh K, Sugimoto J, Sakamoto T (2002) Medullary reticulospinal tract mediating the generalized motor inhibition in cats: II. Functional organization within the medullary reticular formation with respect to postsynaptic inhibition of forelimb and hindlimb motoneurons. Neuroscience 113:65-77. CrossRef Medline

Hafler BP, Choi MY, Shivdasani RA, Rowitch DH (2008) Expression and function of Nkx6.3 in vertebrate hindbrain. Brain Res 1222:42-50. CrossRef Medline
Hägglund M, Borgius L, Dougherty KJ, Kiehn O (2010) Activation of groups of excitatory neurons in the mammalian spinal cord or hindbrain evokes locomotion. Nat Neurosci 13:246-252. CrossRef Medline

Harris-Warrick RM (1993) Pattern generation. Curr Opin Neurobiol 3:982-988. CrossRef Medline

Harris-Warrick RM, Coniglio LM, Barazangi N, Guckenheimer J, Gueron S (1995a) Dopamine modulation of transient potassium current evokes phase shifts in a central pattern generator network. J Neurosci 15:342-358. Medline

Harris-Warrick RM, Coniglio LM, Levini RM, Gueron S, Guckenheimer J (1995b) Dopamine modulation of two subthreshold currents produces phase shifts in activity of an identified motoneuron. J Neurophysiol 74: 1404-1420. Medline

Homma Y, Nonaka S, Matsuyama K, Mori S (1995) Fastigiofugal projection to the brainstem nuclei in the cat: an anterograde PHA-L tracing study. Neurosci Res 23:89-102. CrossRef Medline

Hultborn H, Brownstone RB, Toth TI, Gossard JP (2004) Key mechanisms for setting the input-output gain across the motoneuron pool. Prog Brain Res 143:77-95. Medline

Iwakiri H, Oka T, Takakusaki K, Mori S (1995) Stimulus effects of the medial pontine reticular formation and the mesencephalic locomotor region upon medullary reticulospinal neurons in acute decerebrate cats. Neurosci Res 23:47-53. CrossRef Medline

Jankowska E, Edgley SA (2006) How can corticospinal tract neurons contribute to ipsilateral movements? A question with implications for recovery of motor functions. Neuroscientist 12:67-79. CrossRef Medline

Jankowska E, Cabaj A, Pettersson LG (2005) How to enhance ipsilateral actions of pyramidal tract neurons. J Neurosci 25:7401-7405. CrossRef Medline

Jordan LM (1998) Initiation of locomotion in mammals. Ann N Y Acad Sci 860:83-93. CrossRef Medline

Jordan LM, Liu J, Hedlund PB, Akay T, Pearson KG (2008) Descending command systems for the initiation of locomotion in mammals. Brain Res Rev 57:183-191. CrossRef Medline

Kagan I, Shik ML (2004) How the mesencephalic locomotor region recruits hindbrain neurons. Prog Brain Res 143:221-230. Medline

Karunaratne A, Hargrave M, Poh A, Yamada T (2002) GATA proteins identify a novel ventral interneuron subclass in the developing chick spinal cord. Dev Biol 249:30-43. CrossRef Medline

Kiehn O (2006) Locomotor circuits in the mammalian spinal cord. Annu Rev Neurosci 29:279-306. CrossRef Medline

Kimura Y, Satou C, Fujioka S, Shoji W, Umeda K, Ishizuka T, Yawo H, Higashijima S (2013) Hindbrain V2a neurons in the excitation of spinal locomotor circuits during zebrafish swimming. Current Biol 23:843-849. CrossRef Medline

Kinkhabwala A, Riley M, Koyama M, Monen J, Satou C, Kimura Y, Higashijima S, Fetcho J (2011) A structural and functional ground plan for neurons in the hindbrain of zebrafish. Proc Natl Acad Sci U S A 108:1164-1169. CrossRef Medline

Koyama M, Kinkhabwala A, Satou C, Higashijima S, Fetcho J (2011) Mapping a sensory-motor network onto a structural and functional ground plan in the hindbrain. Proc Natl Acad Sci U S A 108:1170-1175. CrossRef Medline

Lanuza GM, Gosgnach S, Pierani A, Jessell TM, Goulding M (2004) Genetic identification of spinal interneurons that coordinate left-right locomotor activity necessary for walking movements. Neuron 42:375-386. CrossRef Medline

Lee SK, Pfaff SL (2001) Transcriptional networks regulating neuronal identity in the developing spinal cord. Nat Neurosci 4 [Suppl]:1183-1191. Medline

Li S, Misra K, Matise MP, Xiang M (2005) Foxn4 acts synergistically with Mash1 to specify subtype identity of V2 interneurons in the spinal cord. Proc Natl Acad Sci U S A 102:10688-10693. CrossRef Medline

Li WC, Soffe SR, Roberts A (2004) Glutamate and acetylcholine corelease at developing synapses. Proc Natl Acad Sci U S A 101:15488-15493. CrossRef Medline

Liu C, Maejima T, Wyler SC, Casadesus G, Herlitze S, Deneris ES (2010) Pet-1 is required across different stages of life to regulate serotonergic function. Nat Neurosci 13:1190-1198. CrossRef Medline

Liu J, Jordan LM (2005) Stimulation of the parapyramidal region of the neonatal rat brain stem produces locomotor-like activity involving spinal 5-HT7 and 5-HT2A receptors. J Neurophysiol 94:1392-1404. CrossRef Medline 
Lu P, Blesch A, Graham L, Wang Y, Samara R, Banos K, Haringer V, Havton L, Weishaupt N, Bennett D, Fouad K, Tuszynski MH (2012) Motor axonal regeneration after partial and complete spinal cord transection. J Neurosci 32:8208-8218. CrossRef Medline

Lundfald L, Restrepo CE, Butt SJ, Peng CY, Droho S, Endo T, Zeilhofer HU, Sharma K, Kiehn O (2007) Phenotype of V2-derived interneurons and their relationship to the axon guidance molecule EphA4 in the developing mouse spinal cord. Eur J Neurosci 26:2989-3002. Medline

Marder E, Bucher D (2007) Understanding circuit dynamics using the stomatogastric nervous system of lobsters and crabs. Annu Rev Physiol 69: 291-316. CrossRef Medline

Marlinsky VV, Voitenko LP (1991) The effect of procaine injection into the medullary reticular formation on forelimb muscle activity evoked by mesencephalic locomotor region and vestibular stimulation in the decerebrated guinea-pig. Neuroscience 45:753-759. CrossRef Medline

McLean DL, Fetcho JR (2011) Movement, technology and discovery in the zebrafish. Curr Opin Neurobiol 21:110-115. CrossRef Medline

Miles GB, Dai Y, Brownstone RM (2005) Mechanisms underlying the early phase of spike frequency adaptation in mouse spinal motoneurones. J Physiol 566:519-532. CrossRef Medline

Miller JP, Selverston AI (1982) Mechanisms underlying pattern generation in lobster stomatogastric ganglion as determined by selective inactivation of identified neurons. IV. Network properties of pyloric system. J Neurophysiol 48:1416-1432. Medline

Milner KL, Mogenson GJ (1988) Electrical and chemical activation of the mesencephalic and subthalamic locomotor regions in freely moving rats. Brain Res 452:273-285. CrossRef Medline

Molineux ML, Fernandez FR, Mehaffey WH, Turner RW (2005) A-type and T-type currents interact to produce a novel spike latency-voltage relationship in cerebellar stellate cells. J Neurosci 25:10863-10873. CrossRef Medline

Mori S (1987) Integration of posture and locomotion in acute decerebrate cats and in awake, freely moving cats. Prog Neurobiol 28:161-195. CrossRef Medline

Mori S, Nishimura H, Kurakami C, Yamamura T, Aoki M (1978) Controlled locomotion in the mesencephalic cat: distribution of facilitatory and inhibitory regions within pontine tegmentum. J Neurophysiol 41: 1580-1591. Medline

Mori S, Matsui T, Kuze B, Asanome M, Nakajima K, Matsuyama K (1998) Cerebellar-induced locomotion: reticulospinal control of spinal rhythm generating mechanism in cats. Ann N Y Acad Sci 860:94-105. CrossRef Medline

Mullins OJ, Hackett JT, Buchanan JT, Friesen WO (2011) Neuronal control of swimming behavior: comparison of vertebrate and invertebrate model systems. Prog Neurobiol 93:244-269. Medline

Noga BR, Kettler J, Jordan LM (1988) Locomotion produced in mesencephalic cats by injections of putative transmitter substances and antagonists into the medial reticular formation and the pontomedullary locomotor strip. J Neurosci 8:2074-2086. Medline

Noga BR, Kriellaars DJ, Jordan LM (1991) The effect of selective brainstem or spinal cord lesions on treadmill locomotion evoked by stimulation of the mesencephalic or pontomedullary locomotor regions. J Neurosci 11: 1691-1700. Medline

Noga BR, Kriellaars DJ, Brownstone RM, Jordan LM (2003) Mechanism for activation of locomotor centers in the spinal cord by stimulation of the mesencephalic locomotor region. J Neurophysiol 90:1464-1478. CrossRef Medline

Orlovskiü GN (1970) Relations between reticulo-spinal neurons and locomotor regions of the brain stem. Biofizika 15:171-178. Medline

Panayi H, Panayiotou E, Orford M, Genethliou N, Mean R, Lapathitis G, Li S, Xiang M, Kessaris N, Richardson WD, Malas S (2010) Sox1 is required for the specification of a novel p2-derived interneuron subtype in the mouse ventral spinal cord. J Neurosci 30:12274-12280. CrossRef Medline

Paxinos G, Franklin KBJ (2004) The mouse brain in stereotaxic coordinates, compact second edition. San Diego: Academic.

Pereira EA, Muthusamy KA, De Pennington N, Joint CA, Aziz TZ (2008) Deep brain stimulation of the pedunculopontine nucleus in Parkinson's disease. Preliminary experience at Oxford. Br J Neurosurg 22 [Suppl] 1:S41-S44. CrossRef Medline

Perkel DH, Mulloney B (1974) Motor pattern production in reciprocally inhibitory neurons exhibiting postinhibitory rebound. Science 185:181183. CrossRef Medline
Pierani A, Moran-Rivard L, Sunshine MJ, Littman DR, Goulding M, Jessell TM (2001) Control of interneuron fate in the developing spinal cord by the progenitor homeodomain protein Dbxl. Neuron 29:367-384. CrossRef Medline

Prentice SD, Drew T (2001) Contributions of the reticulospinal system to the postural adjustments occurring during voluntary gait modifications. J Neurophysiol 85:679-698. Medline

Roberts A, Li WC, Soffe SR, Wolf E (2008) Origin of excitatory drive to a spinal locomotor network. Brain Res Rev 57:22-28. CrossRef Medline

Schepens B, Drew T (2004) Independent and convergent signals from the pontomedullary reticular formation contribute to the control of posture and movement during reaching in the cat. J Neurophysiol 92:2217-2238. CrossRef Medline

Schepens B, Drew T (2006) Descending signals from the pontomedullary reticular formation are bilateral, asymmetric, and gated during reaching movements in the cat. J Neurophysiol 96:2229-2252. CrossRef Medline

Schwindt P, Crill WE (1977) A persistent negative resistance in cat lumbar motoneurons. Brain Res 120:173-178. CrossRef Medline

Sharma K, Sheng HZ, Lettieri K, Li H, Karavanov A, Potter S, Westphal H, Pfaff SL (1998) LIM homeodomain factors Lhx3 and Lhx4 assign subtype identities for motor neurons. Cell 95:817-828. CrossRef Medline

Shefchyk SJ, Jordan LM (1985) Motoneuron input-resistance changes during fictive locomotion produced by stimulation of the mesencephalic locomotor region. J Neurophysiol 54:1101-1108. Medline

Shefchyk SJ, Jell RM, Jordan LM (1984) Reversible cooling of the brainstem reveals areas required for mesencephalic locomotor region evoked treadmill locomotion. Exp Brain Res 56:257-262. Medline

Shik ML, Severin FV, Orlovskii GN (1966) Control of walking and running by means of electric stimulation of the midbrain. Biofizika 11:659-666. Medline

Sholomenko GN, Funk GD, Steeves JD (1991) Avian locomotion activated by brainstem infusion of neurotransmitter agonists and antagonists. II. gamma-Aminobutyric acid. Exp Brain Res 85:674-681. CrossRef Medline

Sinnamon HM, Stopford CK (1987) Locomotion elicited by lateral hypothalamic stimulation in the anesthetized rat does not require the dorsal midbrain. Brain Res 402:78-86. CrossRef Medline

Steeves JD, Jordan LM (1984) Autoradiographic demonstration of the projections from the mesencephalic locomotor region. Brain Res 307: 263-276. CrossRef Medline

Stefani A, Lozano AM, Peppe A, Stanzione P, Galati S, Tropepi D, Pierantozzi M, Brusa L, Scarnati E, Mazzone P (2007) Bilateral deep brain stimulation of the pedunculopontine and subthalamic nuclei in severe Parkinson's disease. Brain 130:1596-1607. CrossRef Medline

Stosiek C, Garaschuk O, Holthoff K, Konnerth A (2003) In vivo two-photon calcium imaging of neuronal networks. Proc Natl Acad Sci U S A 100: 7319-7324. CrossRef Medline

Szokol K, Glover JC, Perreault MC (2008) Differential origin of reticulospinal drive to motoneurons innervating trunk and hindlimb muscles in the mouse revealed by optical recording. J Physiol 586:5259-5276. CrossRef Medline

Szokol K, Glover JC, Perreault MC (2011) Organization of functional synaptic connections between medullary reticulospinal neurons and lumbar descending commissural interneurons in the neonatal mouse. J Neurosci 31:4731-4742. CrossRef Medline

Takakusaki K, Ohta Y, Mori S (1989) Single medullary reticulospinal neurons exert postsynaptic inhibitory effects via inhibitory interneurons upon alpha-motoneurons innervating cat hindlimb muscles. Exp Brain Res 74:11-23. Medline

Takakusaki K, Habaguchi T, Ohtinata-Sugimoto J, Saitoh K, Sakamoto T (2003a) Basal ganglia efferents to the brainstem centers controlling postural muscle tone and locomotion: a new concept for understanding motor disorders in basal ganglia dysfunction. Neuroscience 119:293-308. CrossRef Medline

Takakusaki K, Kohyama J, Matsuyama K (2003b) Medullary reticulospinal tract mediating a generalized motor inhibition in cats: III. Functional organization of spinal interneurons in the lower lumbar segments. Neuroscience 121:731-746. CrossRef Medline

Talpalar AE, Endo T, Löw P, Borgius L, Hägglund M, Dougherty KJ, Ryge J, Hnasko TS, Kiehn O (2011) Identification of minimal neuronal networks involved in flexor-extensor alternation in the mammalian spinal cord. Neuron 71:1071-1084. CrossRef Medline 
Travers JB, Dinardo LA, Karimnamazi H (1997) Motor and premotor mechanisms of licking. Neurosci Biobehav Rev 21:631-647. CrossRef Medline

Waldrop TG, Iwamoto GA (2006) Point: supraspinal locomotor centers do contribute significantly to the hyperpnea of dynamic exercise. J Appl Physiol 100:1077-1079. Medline

Willows AO (1980) Physiological basis of feeding behavior in Tritonia diomedea. II. Neuronal mechanisms. J Neurophysiol 44:849-861. Medline

Wilson JM, Hartley R, Maxwell DJ, Todd AJ, Lieberam I, Kaltschmidt JA, Yoshida Y, Jessell TM, Brownstone RM (2005) Conditional rhythmicity of ventral spinal interneurons defined by expression of the $\mathrm{Hb} 9$ homeodomain protein. J Neurosci 25:5710-5719. CrossRef Medline

Wilson JM, Dombeck DA, Díaz-Ríos M, Harris-Warrick RM, Brownstone RM (2007) Two-photon calcium imaging of network activity in XFPexpressing neurons in the mouse. J Neurophysiol 97:3118-3125. CrossRef Medline
Wilson JM, Blagovechtchenski E, Brownstone RM (2010) Genetically defined inhibitory neurons in the mouse spinal cord dorsal horn: a possible source of rhythmic inhibition of motoneurons during fictive locomotion. J Neurosci 30:1137-1148. CrossRef Medline

Zaaimi B, Edgley SA, Soteropoulos DS, Baker SN (2012) Changes in descending motor pathway connectivity after corticospinal tract lesion in macaque monkey. Brain 135:2277-2289. CrossRef Medline

Zaporozhets E, Cowley KC, Schmidt BJ (2004) A reliable technique for the induction of locomotor-like activity in the in vitro neonatal rat spinal cord using brainstem electrical stimulation. J Neurosci Methods 139:33-41. CrossRef Medline

Zaporozhets E, Cowley KC, Schmidt BJ (2006) Propriospinal neurons contribute to bulbospinal transmission of the locomotor command signal in the neonatal rat spinal cord. J Physiol 572:443-458. CrossRef Medline

Zhou Y, Yamamoto M, Engel JD (2000) GATA2 is required for the generation of V2 interneurons. Development 127:3829-3838. Medline 